\title{
RECESSions and FinanCial DisRuptions in EMERGing Markets: A BIRD's EYe VIEW
}

\author{
Stijn Claessens \\ International Monetary Fund, University of Amsterdam, \\ and Centre for Economic Policy Research \\ M. Ayhan Kose \\ International Monetary Fund \\ Marco E. Terrones \\ International Monetary Fund
}

The global financial crisis of 2008-09 led to massive interruptions in cross-border financial and trade flows. As a result of the crisis, virtually all of the advanced economies and many emerging market countries experienced recessions over the past two years. These recessions coincided with various forms of financial disruptions, such as severe contractions in the supply of credit and sharp declines in asset prices. Understanding the linkages between recessions and periods of financial disruptions has become a new challenge for macroeconomic research.

This paper provides a brief overview of the linkages between recessions and financial disruptions for a large group of emerging market economies. In particular, we explore the following questions. First, what are the main features of recessions and financial disruptions in emerging markets? Second, how synchronized are these events across emerging markets? Third, how does the coincidence between recessions and financial disruptions affect

We would like to thank our discussant, Norman Loayza, for useful suggestions, and David Fritz and Ezgi Ozturk for providing outstanding research assistance. The views expressed in this paper are those of the authors and do not necessarily represent those of the International Monetary Fund (IMF) or IMF policy.

Monetary Policy under Financial Turbulence, edited by Luis Felipe Céspedes, Roberto Chang, and Diego Saravia, Santiago, Chile. (C) 2011 Central Bank of Chile. 
macroeconomic outcomes? For each of these questions, we contrast the experience of emerging market economies with that of a group of advanced countries. We also provide a brief case study analysis of recessions and financial disruptions in Chile and consider how the Chilean case compares to other emerging markets.

To address these questions, we construct a comprehensive dataset of key macroeconomic and financial variables covering 23 emerging market countries over the period 1978:1 to 2007:4. Using a standard business cycle dating algorithm, we first document turning points in our main variables of interest, including output, credit, and equity prices. We identify 84 recessions, 102 credit contractions, and 139 equity price declines for these countries over this period. When recessions, credit contractions, and equity price declines fall into the top quartiles of all recessions, contractions, and declines, we define them as severe recessions, credit crunches, and equity price busts. We also identify 20 recessions associated with episodes of financial crises in emerging markets.

Armed with this rich set of events, we conduct a number of exercises. First, we examine the main characteristics of these recessions and financial market disruptions-in terms of duration and severity-and the behavior of major macroeconomic and financial variables around these events. Next, we document the coincidence of recessions and credit crunches, equity price busts, and financial crises, and analyze the implications of recessions for key macroeconomic aggregates. We also examine how these features vary across regions, and we consider how episodes of recessions and financial disruptions in emerging markets are different from those in advanced economies.

In light of the facts we document for the broader set of emerging markets, we next explore the main features of recessions and financial disruptions in Chile. We focus on the Chilean case for a few reasons. First, the growth performance of the Chilean economy has been a major success story over the past three decades. Second, Chile's macroeconomic and financial sector policies were instrumental in moderating business and financial cycles in this period. Third, the relative success of Chile in managing the adverse effects of the recent global financial crisis makes it an interesting case study. We briefly review the three recession episodes Chile experienced prior to the recent crisis and examine the macroeconomic implications of disruptions in its credit and equity markets. We put our findings 
into context by providing a review of the related literature regarding business cycles in Chile.

Our study contributes to a large body of research on business cycles and growing research analyzing the interactions between macroeconomic and financial variables over the business cycle. While most empirical work focuses on advanced countries, there is a rich set of theoretical studies examining the implications of financial disruptions for the real economy in the context of emerging market countries. Krugman (1999) and Aghion, Bacchetta, and Banerjee (2001), for example, show how a combination of financial market imperfections and currency mismatches can translate into highly volatile business cycle fluctuations in emerging markets. Using the financial accelerator construct, Céspedes, Chang, and Velasco (2004) study how linkages between exchange rates and corporate balance sheets affect macroeconomic outcomes in small open economies. ${ }^{1}$ Caballero and Krishnamurthy (1998) and Schneider and Tornell (2004) model how, also because of balance sheet constraints, fluctuations in credit and asset markets can translate into boom-bust cycles in emerging market economies. ${ }^{2}$

Several empirical studies provide evidence of these interactions in the context of advanced countries. For example, there is a large empirical literature for advanced countries analyzing the dynamics of business cycles, asset price fluctuations, and credit cycles (see Bernanke and Gertler, 1989; Borio, Furfine, and Lowe, 2001), including studies using microeconomic data (banks or corporations) (see Bernanke, Gertler, and Gilchrist, 1996; Kashyap and Stein, 2000). Recent research also considers how interactions between financial and real activity variables can vary during recessions in advanced countries. For example, Claessens, Kose, and Terrones (2009) report that recessions in advanced countries associated with episodes of sharp declines in credit or asset prices are typically longer and deeper than normal recessions. However, studies of interactions

1. In particular, Céspedes, Chang, and Velasco (2004) extend the model of Bernanke, Gertler, and Gilchrist (1999) and show that negative external shocks can have a magnified impact on output because of the balance sheet effects stemming from a (real) devaluation in emerging markets.

2. Recent research also considers how fluctuations in asset prices affect the value of collateral required for international funding. Mendoza (2010) shows that when borrowing levels are high relative to asset values, shocks to collateral constraints can generate an amplification mechanism, like Fisher's (1933) debt-deflation mechanism, and can result in a large impact on output. 
between real and financial sectors during periods of downturns in emerging markets are rather limited.

We also contribute to a branch of the literature on business cycles that aims to identify the turning points in macroeconomic and financial variables using various methodologies. The classical methodology of dating business cycles, applied here as well, goes back to Burns and Mitchell (1946). It has been widely used over the years to study recessions in advanced countries. Only a few studies use this methodology to analyze the turning points of business cycles in emerging markets with quarterly data. ${ }^{3}$ These studies focus mostly on the behavior of output or employ small samples of countries over relatively short time periods.

There is, of course, a large literature analyzing various aspects of business cycles in emerging economies using a variety of methods. For example, Kose (2002) and Neumeyer and Perri (2005) use stochastic dynamic models to consider the implications of various shocks for business cycles in emerging markets. Chang, Kaltani, and Loayza (2009) and Kose, Prasad, and Terrones (2006) analyze empirically the linkages between long-term growth and short-term business cycle volatility using panel regressions. Kose, Prasad, and Terrones (2003) examine the synchronization of cycles across emerging and advanced countries using various methods, including dynamic factor models. However, none of these papers consider the dynamics of financial cycles in emerging markets.

Importantly, the links between real and financial variables during recessions have yet to be analyzed using a comprehensive dataset of a large number of emerging market countries over a long period. ${ }^{4}$ Most studies are limited to a small number of countries or present case studies of individual episodes. Others focus specifically on the behavior of real and financial variables surrounding financial crises, notably Reinhart and Rogoff (2009). Building on earlier work in the context of advanced economies (Claessens, Kose, and Terrones,

3. Calderón and Fuentes (2006) consider a sample of 14 emerging market economies over 1980-2005. Gupta and Miniane (2009) analyze recessions and recoveries using quarterly data on eight emerging countries for the 1980-2008 period. Du Plessis (2006) studies seven emerging economies using a data sample mostly covering the period 1980-2004. Using annual data, Hong, Lee, and Tang (2010) examine the links between macroeconomic fluctuations and financial crises in 21 Asian emerging and developing economies.

4. Claessens, Kose, and Terrones (forthcoming) provide a detailed analysis of business and financial cycles in advanced countries and emerging markets. 
2009), this paper documents the basic stylized facts of recessions and financial market disruptions in emerging markets.

The paper is structured as follows. Section 1 presents our dataset and methodology. Section 2 examines the basic characteristics of recessions and episodes of credit contractions and equity price declines in emerging markets and compares these with the experiences of advanced countries. This section also studies the implications of recessions associated with credit crunches, equity price busts, and financial crises. In section 3, we provide a brief discussion of recessions and financial disruptions in Chile and compare the Chilean episodes with those in other emerging markets. Section 4 concludes.

\section{Database and Methodology}

We employ a comprehensive database covering 23 emerging market countries and 21 Organization for Economic Cooperation and Development (OECD) countries over the period 1978:1 to 2007:4. The emerging market countries in our sample are Argentina, Brazil, Chile, China, Colombia, Costa Rica, Ecuador, Hong Kong, India, Indonesia, Israel, Malaysia, Mexico, Peru, Philippines, Singapore, South Africa, South Korea, Taiwan, Thailand, Turkey, Uruguay, and Venezuela. ${ }^{5}$ We compare the features of recessions and financial disruptions in emerging economies with those of advanced OECD countries. The advanced countries in our sample are Australia, Austria, Belgium, Canada, Denmark, Finland, France, Germany, Greece, Ireland, Italy, Japan, Netherlands, New Zealand, Norway, Portugal, Spain, Sweden, Switzerland, the United Kingdom, and the United States. ${ }^{6}$

The emerging and advanced countries in our sample account collectively for more than 90 percent of global output. However, there are significant differences between the two groups. For example, per capita income level is typically about one-third lower in emerging

5. The emerging markets roughly correspond to those included in the MSCI Emerging Markets Index. The main differences are that we drop some countries because of data limitations (Czech Republic, Egypt, Hungary, Jordan, Morocco, Pakistan, Poland, and Russia), while we include a number of other emerging markets (Costa Rica, Ecuador, Hong Kong, Singapore, and Venezuela). We provide detailed information about the database in Claessens, Kose, and Terrones (forthcoming).

6. In Claessens, Kose, and Terrones (forthcoming), we study business and financial cycles in advanced countries for the period 1960:1 to 2007:4. 
markets than in the typical advanced country. In terms of overall economic size, total GDP (in U.S. dollars) is also lower for the typical emerging market. Relative to its size, however, the typical emerging market country in the sample trades more with the rest of the world than the typical advanced economy. Specifically, in 2005, the standard trade openness ratio (exports plus imports as a share of GDP) is close to 80 percent for the emerging market group, while it is about 50 percent for the advanced countries group. In terms of financial linkages with the rest of the world, the advanced economies are definitely more integrated with the global financial markets than emerging countries are.

\subsection{Macroeconomic and Financial Variables}

Our analysis focuses on recessions and financial market disruptions, which dictates our data choices. Although our main database contains a large number of macroeconomic aggregates, we provide statistics here for only a smaller set for the sake of brevity. The quarterly time series of macroeconomic variables are seasonally adjusted, whenever necessary, and in constant prices. These series are collected from various sources, including the International Monetary Fund's International Financial Statistics (IFS) and the OECD. The financial variables we consider are credit and equity prices. Credit series are obtained from IFS and defined as claims on the private sector by deposit money banks. These are also the series used in earlier cross-country studies on credit dynamics (for example, Mendoza and Terrones, 2008). ${ }^{7}$ Equity price indexes are also from IFS and generally cover the main local stock exchanges. All financial variables are converted into real terms using their country's respective consumer price indexes (CPI). ${ }^{8}$

7. Many papers examine the behavior of aggregate credit measures during recessions or financial crises. Chari, Christiano, and Kehoe (2008) and Cohen-Cole and others (2008) highlight that it is important to go beyond aggregate measures (for example, differentiating credit to corporations from credit to households) to study the dynamics of credit markets especially in the context of the latest financial crisis in the United States. However, this is extremely difficult, if not impossible, to do in the context of our large cross-country coverage.

8. Another major financial variable is the house price, but house prices are available for only a small number of emerging market economies. Claessens, Kose, and Terrones (2009) provide an analysis of disruptions in housing markets using the data for advanced countries. 


\subsection{Identifying Turning Points}

Before analyzing recessions and their interactions with periods of financial stress, it is necessary to determine the dates of these various events. The methodology we employ focuses on changes in the levels of variables to identify cycles. This is consistent with the guiding principles of the National Bureau of Economic Research (NBER), which is the unofficial arbiter of U.S. business cycles. This methodology assumes that a recession begins just after the economy reaches a peak and ends as the economy reaches a trough. The methodology determines the peaks and troughs of any given series by first searching for maxima and minima over a given period of time. It then selects pairs of adjacent, locally absolute maxima and minima that meet certain censoring rules requiring a certain minimal duration of cycles and phases.

In particular, we employ the algorithm introduced by Harding and Pagan (2002b), which extends the so called BB algorithm developed by Bry and Boschan (1971) to identify the cyclical turning points in the log-level of a series. ${ }^{9}$ We search for maxima and minima over a given period of time and then select pairs of adjacent, local maxima and minima that meet certain censoring rules, that is, a certain minimal duration for cycles and phases. In particular, the algorithm requires the durations of a complete cycle and of each phase to be at least five quarters and two quarters, respectively. Specifically, a peak in a quarterly series $y_{t}$ occurs at time $t$ if

$$
\left\{\left[\left(y_{t}-y_{t-2}\right)>0,\left(y_{t}-y_{t-1}\right)>0\right] \text { and }\left[\left(y_{t+2}-y_{t}\right)<0,\left(y_{t+1}-y_{t}\right)<0\right]\right\} \text {. }
$$

Similarly, a cyclical trough occurs at time $t$ if

$$
\left\{\left[\left(y_{t}-y_{t-2}\right)<0,\left(y_{t}-y_{t-1}\right)<0\right] \text { and }\left[\left(y_{t+2}-y_{t}\right)>0,\left(y_{t+1}-y_{t}\right)>0\right]\right\} \text {. }
$$

9. The algorithm we employ is known as the BBQ algorithm since it is applied to quarterly data. It is possible to use a different algorithm, such as a Markov switching (MS) model (Hamilton, 2003). Harding and Pagan (2002a) compare the MS and BBQ algorithms and conclude that the BBQ is preferable because the MS model depends on the validity of the underlying statistical framework. Artis, Kontolemis, and Osborn (1997) and Harding and Pagan (2002b) also use the BBQ methodology. 
We then define a complete cycle from one peak to the next with two phases, the contraction phase (from peak to trough) and the expansion phase (from trough to peak). Our main macroeconomic variable is output (GDP), which provides the broadest measure of economic activity.

We use the same approach to identify the turning points in our financial series. ${ }^{10}$ In terms of financial variables, we consider cycles in real credit and equity prices. We are especially interested in what happens when recessions and financial disruptions coincide. To investigate these coincidences, we apply a simple dating rule for whether or not a specific recession is associated with a credit crunch or an equity price bust. If a recession episode starts at the same time as or after the start of an ongoing credit crunch or equity price bust, then we consider the recession to be associated with the respective crunch or bust. By definition, this rule describes a timing association (or coincidence) between the two events, but does not imply a causal link.

The main characteristics of cyclical phases are their duration and amplitude. Since we are mainly interested in examining contractions (recessions in output and declines in financial variables), we study these characteristics for contractions only. The duration of a contraction, $D^{c}$, is the number of quarters, $k$, between a peak and the next trough. The amplitude of a contraction, $A^{c}$, measures the change in $y_{t}$ from a peak $\left(y_{0}\right)$ to the next trough $\left(y_{k}\right)$, that is, $A^{c}=y_{k}-y_{0}$. For output, we consider another widely used measure, cumulative loss, which combines information on duration and amplitude to proxy for the overall cost of a contraction. The cumulative loss, $F^{c}$, during a contraction with duration $k$ is defined as

$$
F^{c}=\sum_{j=1}^{k}\left(y_{j}-y_{0}\right)-\frac{A^{c}}{2} .
$$

We further classify recessions based on the extent of decline in output. In particular, we call recessions mild or severe if the peak-to-trough output drop falls within the bottom or top quartile, respectively, of all output drops in each group of countries we

10. In the case of equity prices, the constraint that the contraction phase must last at least two quarters is ignored if the quarterly decline exceeds 20 percent because equity prices can display much intraquarter variation leading to large differences between peaks and troughs. 
study. Similarly, a credit crunch is defined as a peak-to-trough contraction in credit that falls within the top quartile of all credit contractions. ${ }^{11}$ An equity price bust is defined as a peak-to-trough decline that falls within the worst quartile of all price declines. A severe credit crunch or equity price bust is defined as the top oneeighth of all credit contractions or equity price busts.

How successful is our algorithm in replicating the well-known turning points of U.S. business cycles as determined by the NBER? Our algorithm replicates the dates of the NBER very well. According to the NBER, the United States experienced seven recessions over the 1960-2007 period. Our algorithm provides exact matches for four of these seven peak and trough dates and is only a quarter early in dating the remaining peaks and troughs. ${ }^{12}$ The main features of our business cycles are quite similar to those of the NBER, as well. For example, the average duration of U.S. business cycles based on our turning points is the same as that reported by the NBER. In addition, the average peak-to-trough decline in output during U.S. recessions is about 1.7 percent based on our dating and 1.4 percent based on NBER dating.

\section{Exploring the Downside of Fluctuations}

We start by measuring the frequency of recessions and their coincidence with financial disruptions. We then describe the basic features of recessions and their dynamics. Next, we take a look at the implications of credit contractions and equity price declines in financial markets. Finally, we explore the effects of recessions in emerging markets when they are accompanied by credit crunches, equity price busts, or financial crises.

11. To determine the credit crunch episodes, we use changes in the volume of (real) credit. In the literature, crunches are typically defined as excessive declines in the supply of credit that cannot be explained by cyclical changes in demand (see Bernanke and Lown, 1991). It is very difficult, however, to separate the roles played by demand and supply factors in the actual volume of credit extended. An alternative methodology to identify credit crunch episodes would be to consider price measures, that is, to track changes in interest rates over time, but data limitations do not allow us to employ such measures for our large sample of countries.

12. The differences between our turning points and those of the NBER are due to the fact that the NBER uses monthly data for various activity indicators (including industrial production, employment, personal income net of transfer payments, and volume of sales from the manufacturing and wholesale retail sectors), whereas we use only quarterly output series to identify cyclical turning points. 


\subsection{Frequency and Synchronization of Recessions and Financial Disruptions}

How many recessions and financial market disruptions did the emerging market and advanced economies experience over 1978-2007? In emerging market countries, we identify 84 output recessions (21 of which are severe), 102 credit contractions (25 crunches), and 139 declines in equity prices (34 busts) (see figure 1). For the sample of advanced countries, we identify 81 output recessions (20 of which are severe), 71 credit contractions (17 crunches), and 152 declines in equity prices ( 38 busts). Although the samples of events appear to be similar in terms of numbers, our data set for emerging markets often includes countries with shorter time series than those for advanced countries, which are typically for the full period.

In terms of recessions and financial market disruptions, the events we analyze display a considerable overlap: 14 and 25 recession episodes in emerging markets are associated with credit crunches and equity price busts, respectively. In other words, in about one out of six recessions, a credit crunch was also underway, and in about one in three recessions, an equity price bust was occurring. In terms of financial crises, of the 84 recessions, 20 are associated with crises dated by Laeven and Valencia (2008). Of these 20, five were also credit crunches and ten were equity price busts, and of these, four were both credit crunches and equity price busts.

We next examine the synchronization of recessions, credit contractions, and equity price declines across countries. Our synchronization measure is simply the fraction of countries experiencing the same event at about the same time. For recessions, panel A in figure 2 shows the fraction over the period 1978:1 to 2007:4. Recessions in emerging markets do occur in bunches. The first synchronized recession episode is related to the debt crisis of the 1980s, with the frequency of recessions increasing first in 1982 and then again in the mid-1980s. Following this period, recessions are less common across emerging market countries until the Asian crisis of 1998-99, when a relatively larger fraction of countries (about 40 percent) suffered recessions. Another increase of recessions in emerging markets coincides with the 2001 U.S. recession. 


\section{Figure 1. Number of Recessions and Financial Disruptions ${ }^{\mathrm{a}}$}

\section{A. Emerging markets}

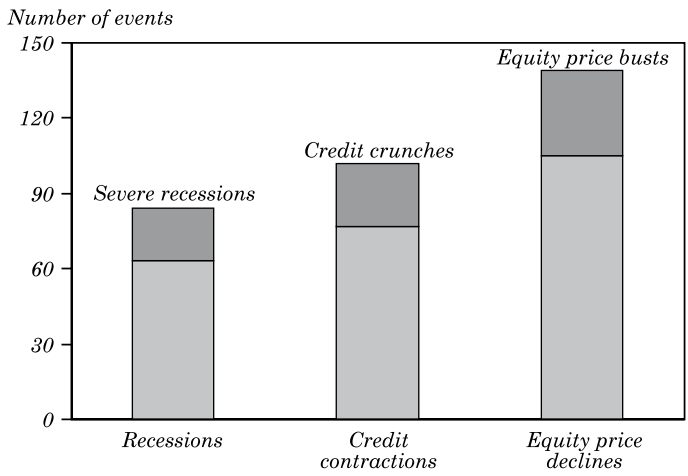

\section{B. Advanced countries}

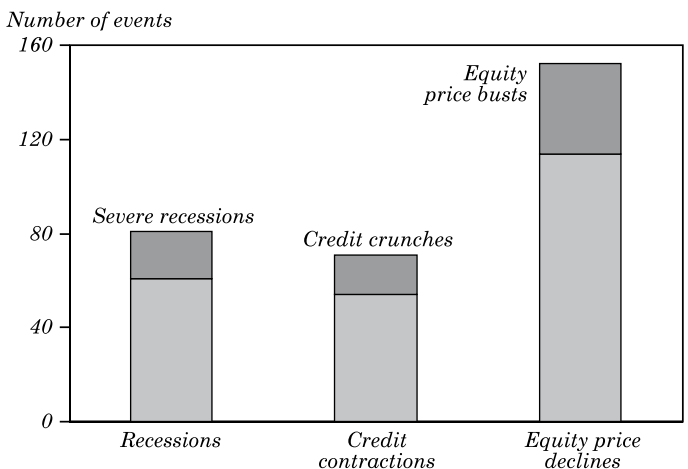

Source: Authors' calculations.

a. Each bar refers to the total number of the respective events. Severe recessions are those in which the peak-totrough decline in output is in the top 25 percent of all recession-related output declines in the respective group. Credit crunches and asset price busts correspond to peak-to-trough declines in credit and asset prices that are in the top 25 percent of all episodes of credit contractions and asset price declines, respectively. 
Figure 2. Synchronization of Recessions and Financial Disruptions $^{\text {a }}$

A. Recessions

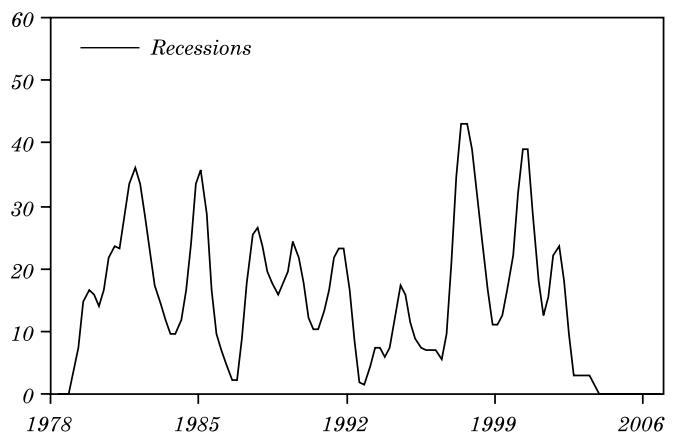

B. Recessions and equity price declines

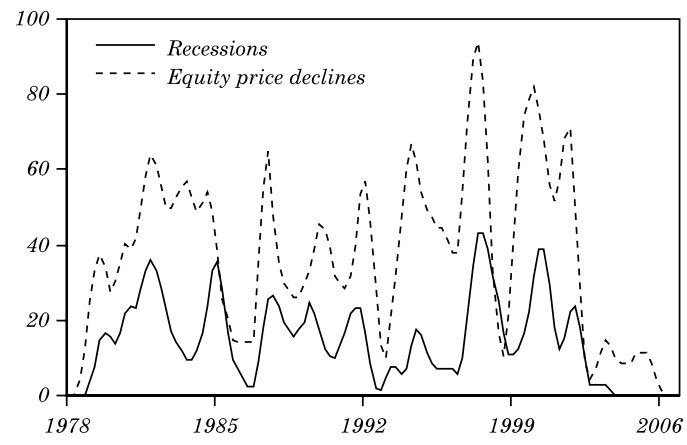

C. Recessions and credit contractions

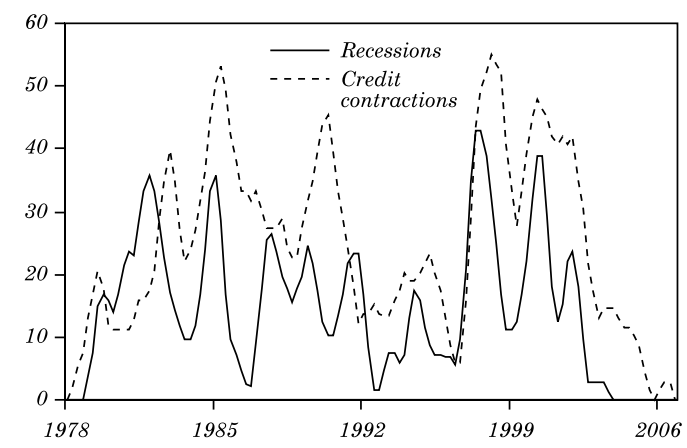

Source: Authors' calculations.

a. Each line represents the share of emerging market countries experiencing recessions, credit contractions, or equity price declines. 
We also consider the coincidence of contraction episodes in financial markets and their overlap with recessions (figure 2, panels $\mathrm{B}$ and $\mathrm{C}$ ). Equity prices exhibit the highest degree of synchronization, reflecting the extensive integration of stock markets around the world. More than half of the emerging markets experienced a sustained decline in equity prices during the highly synchronized episodes of equity market turbulence. Credit contractions are somewhat less synchronized across countries, but still there are eight years in which more than 40 percent of countries experienced credit contractions.

In emerging market economies, recessions tend to coincide most closely with contractions in domestic credit and somewhat less with declines in equity prices. This is evident in the fact that the fractions of countries experiencing recessions is more highly correlated with the fractions suffering credit contractions than with those suffering bear equity markets. While credit contractions are particularly closely associated with recessions, we cannot infer causality herenor for any other relationship we depicted: credit could be declining because of the recession or a decline in credit could be leading to the recession episode.

These findings echo the results reported by Claessens, Kose, and Terrones (2009) in the context of advanced countries. In that paper, we document that recessions in advanced countries are also highly synchronized events. They are bunched in four periods over the past 40 years-namely, the mid-1970s, the early 1980s, the early $1990 \mathrm{~s}$, and the early $2000 \mathrm{~s}$ - and often coincide with global shocks. Importantly, these findings suggest that globally synchronized recessions are longer and deeper than other recessions. Advanced countries also go through simultaneous episodes of credit contractions and declines in equity prices. Recessions tend to coincide with contractions in domestic credit and declines in equity prices in most advanced countries. Credit contractions, in particular, are closely associated with recessions. Equity prices exhibit the highest degree of synchronization, reflecting the extensive integration of equity markets across advanced economies.

\subsection{Basic Features of Recessions}

Recessions can be characterized according to their intensity, duration, cost, and severity. This section addresses each of these features in turn. 


\subsubsection{Intensity of recessions}

Table 1 presents the main characteristics of the recessions in our sample of emerging markets and advanced countries. Since we are interested in the experience of the typical country, we most often focus on medians, as they are less affected by the presence of outliers. However, we also report the averages and standard deviations measuring the dispersion in our sample. A typical emerging market country experienced about four recessions. There is no apparent pattern to the number of recessions across countries, although some regions do stand out. For example, the Asian emerging markets experienced just two recessions, on average, whereas the emerging economies in Latin America witnessed close to five episodes. The median number of recessions in a typical advanced economy is three, but the average is close to four. Since the length of available data series differs slightly across the emerging countries in our sample, it is difficult to compare the absolute number of recessions across country groups and regions.

A better metric for analyzing the incidence of recessions is the proportion of time a country has been in a recession, simply defined as the fraction of quarters the economy is in a recession over the full sample period. According to this metric, the typical emerging market went through a period of contraction for less than 20 percent of the sample duration. Since this metric adjusts for the length of data series, we can compare groups by region and level of development. The fraction of time spent in recession is typically 50 percent longer for Latin American emerging economies than for Asian emerging markets. In the case of advanced countries, the intensity measure is around 13 percent, on average, which is much less than that of emerging markets.

\subsubsection{Duration of recessions}

There is no noticeable difference across emerging and advanced countries in terms of the average duration of recessions. In emerging markets, an average recession lasts about four quarters (3.92), while in advanced countries, the average recession lasts slightly less (3.73 quarters). In emerging markets, the shortest recession is (by definition) two quarters and the longest 13 quarters (in South Africa over the period 1989:3-1992:4). Roughly 35 percent of all recessions are short-lived, meaning only two quarters of output decline. The average duration of recessions does not differ much between emerging markets in Asia and Latin America. 


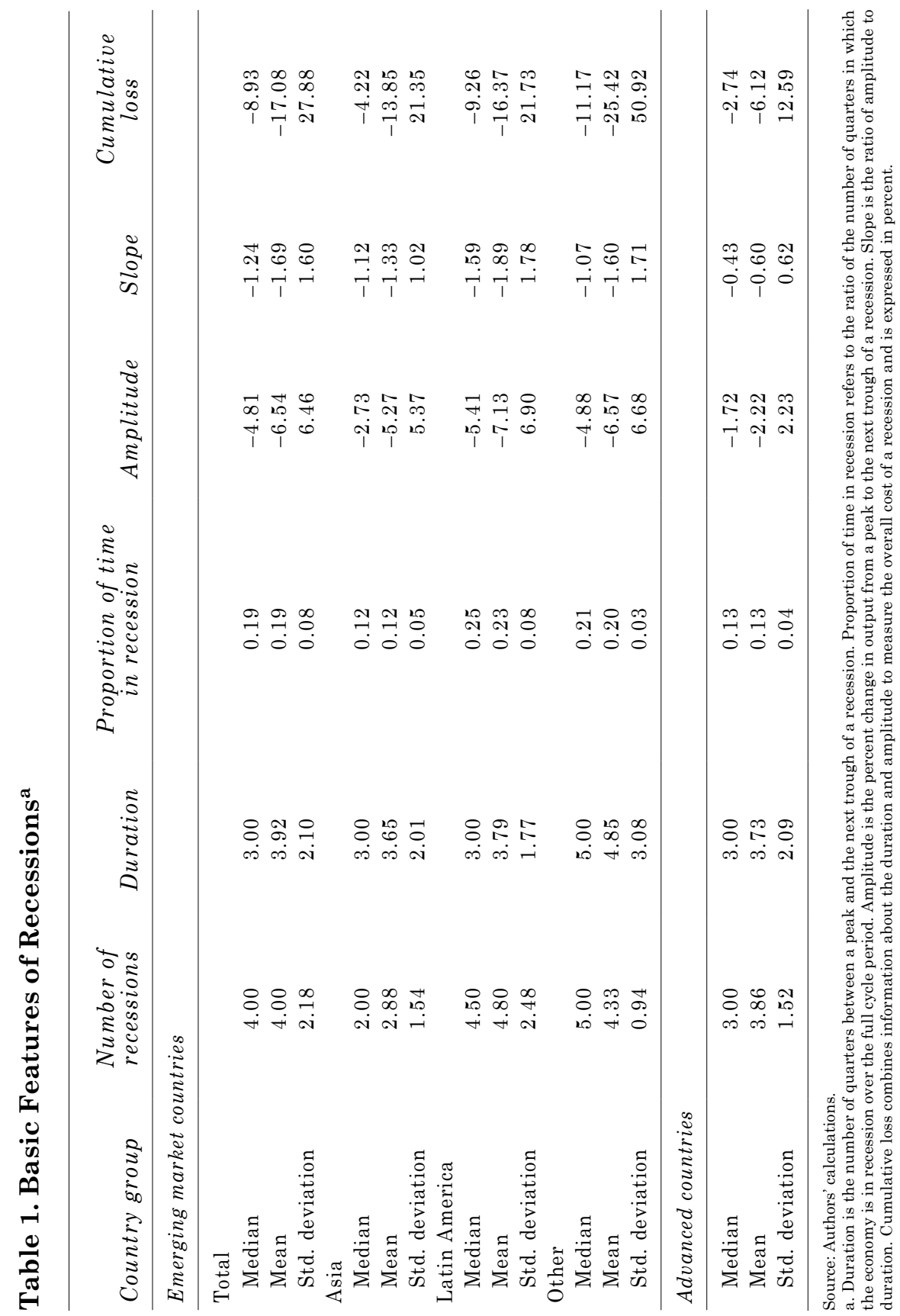




\subsubsection{Cost and violence of recessions}

The median (average) decline in output from peak to trough, or the recession's amplitude, is about 4.8 percent (6.5 percent) in emerging markets. It ranges from about 1.7 percent for the typical recession in Costa Rica to more than 10 percent for recessions in Peru, Thailand, and Venezuela. The typical recession in Asian emerging markets is two times less costly than that in Latin American countries. However, the amplitude of a typical emerging country recession is about three times larger than that of an advanced country.

The slope (violence) of a recession, defined as the ratio of its amplitude to duration, is typically also much larger in emerging economies than advanced countries, at -1.2 versus -0.4 . This suggests that recessions in emerging market countries are more violent macroeconomic events. Consistent with the findings for amplitudes, recessions in Asian emerging markets tend to be less violent than those in Latin America.

Recessions in emerging market countries lead to much larger cumulative losses than those in advanced economies. In particular, a typical recession is associated with more than three times larger cumulative loss in an emerging market country than it is for an advanced economy ( 9 percent versus 3 percent). While the cumulative loss for a typical (median) recession is about 9 percent in emerging markets, the average loss is about 17 percent, showing that the distribution is very skewed to the right. The cumulative loss of a recession in Latin American emerging markets is two times larger than that in emerging Asia.

These findings are consistent with the widely documented result that macroeconomic fluctuations in emerging markets are typically more pronounced than those in advanced economies (Kose, Prasad, and Terrones, 2006 and 2009). More importantly, they indicate that the downside of macroeconomic fluctuations in emerging market economies tends to be much sharper than those in advanced countries. While recessions in emerging markets are typically not much more frequent and not longer than those in advanced countries, when recessions occur in emerging markets, they tend to worsen at a more rapid pace and become deeper than those in advanced countries. This is, in part, due to many recessions in emerging markets being accompanied by financial market disruptions. 


\subsubsection{Severity of recessions}

A recession is classified as severe when the peak-to-trough decline in output is in the top one-quarter, or greater than 8.4 percent. We present the main features of such episodes in table 2 . While a number of emerging market countries did not experience severe recessions in the sample period, Argentina went through four such episodes, and Venezuela, Peru, and Turkey experienced two of them. The 21 such recessions in our sample typically lasted for five quarters, a quarter longer than the average recession. By construction, severe recessions are much more costly than other recessions, with a median decline of about 13 percent and a cumulative loss of about 27 percent, the latter over three times more costly than that of other recessions. These recessions are also more virulent, with a slope coefficient three times greater than that of other recessions. Tables 1 and 2 together suggest that, compared with advanced countries, the typical recession in emerging economies is equivalent to a severe recession in advanced countries in terms of its amplitude and cumulative loss.

A further illustration of the distribution of recessions is provided in figure 3. Most recessions in emerging markets lasted four quarters or less, and the overwhelming majority of these were mild to moderate in depth. Specifically, roughly 30 percent of all recessions lasted two quarters, 40 percent lasted three-four quarters, and 30 percent lasted five quarters or more. This figure also shows that the shorter recessions tended to be milder. Of the severe recessions, however, most lasted more than five quarters. To examine the changes in these features over time, we split our sample into two subperiods: 1978-92 and 1993-2007. Comparing the two subperiods shows that, unlike the well-documented pattern of the Great Moderation of cycles in advanced countries up until the latest crisis, the depth and duration of recessions in emerging markets have not moderated over time.

\subsection{Dynamics of Recessions}

The dynamics of adjustment around recessions in emerging markets differ substantially from those in advanced countries. Figure 4 presents a comparison of the typical behavior of some macroeconomic and financial variables during recessions in emerging markets and advanced countries. The typical decline in the year-over-year growth rate of output in emerging markets from the peak to the trough of 


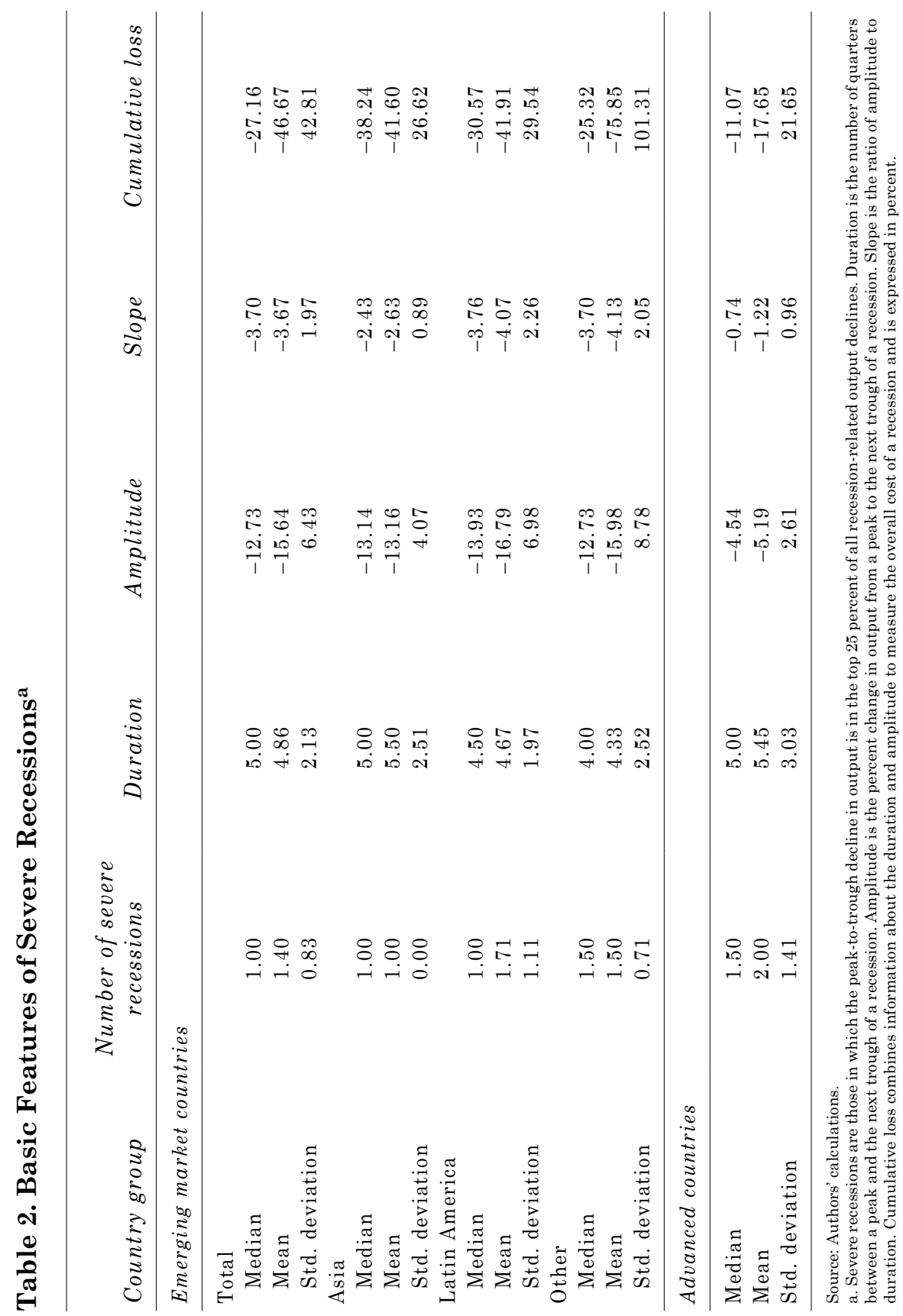


Figure 3. Recessions in Emerging Markets: Duration and Amplitude ${ }^{a}$

A. Duration and amplitude: full period (1978:1 to 2007:4)

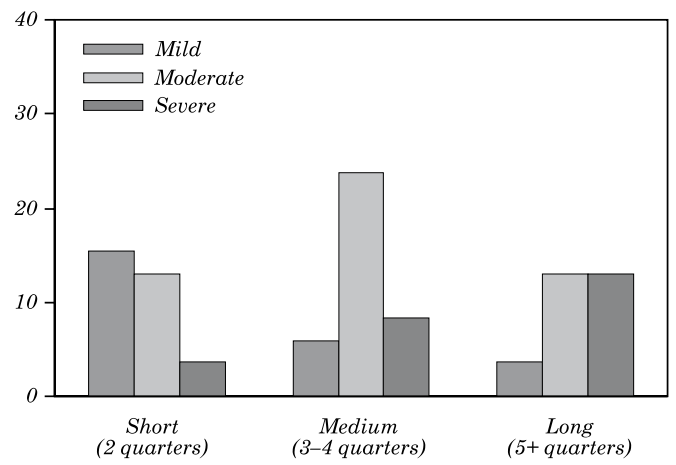

B. Duration: subperiods

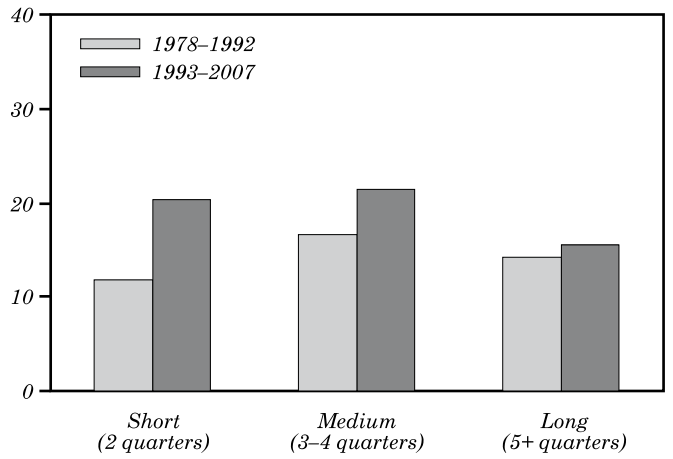

C. Amplitude: subperiods

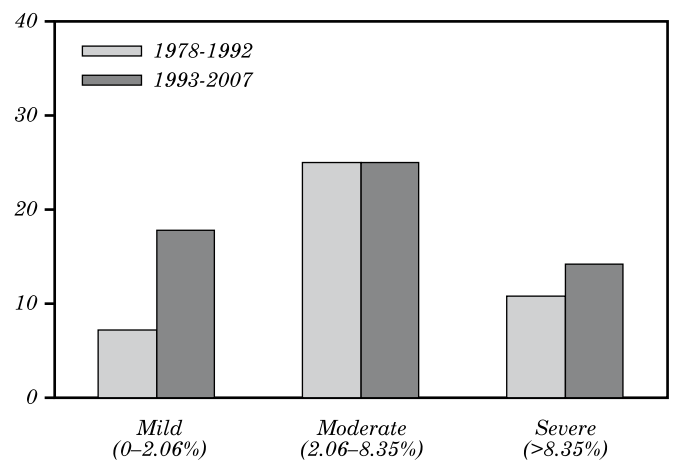

Source: Authors' calculations.

a. Each bar represents the share of total recessions in a particular category. Duration is the number of quarters from peak to trough in a recession. Amplitude is the percent change in output from peak to trough in a recession. 
a recession is three times larger than in advanced countries (10 percentage points versus 3 percentage points). Industrial production also displays a much sharper decline in emerging markets relative to advanced countries.

Figure 4. Recession Dynamics: Emerging Markets and Advanced Countries ${ }^{a}$

Annual percent change

\section{A. Output}

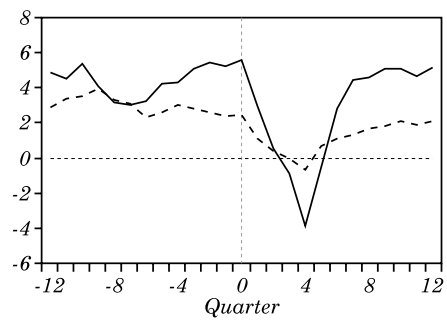

C. Exports

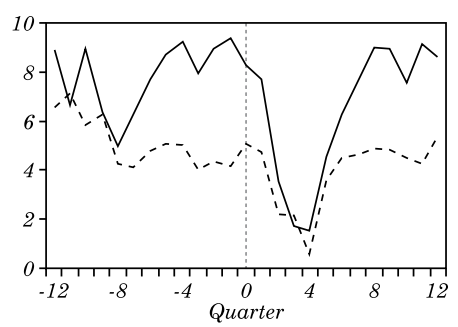

E. Private credit

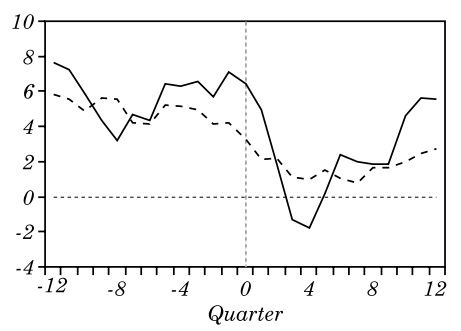

B. Industrial production

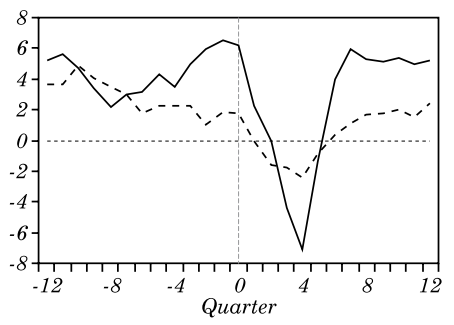

D. Imports

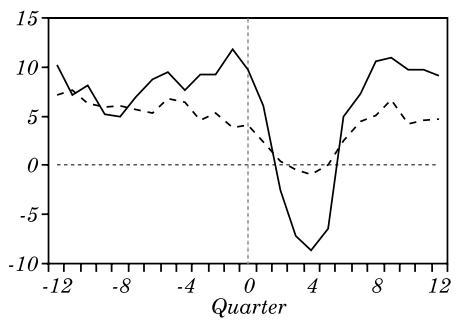

F. Equity prices

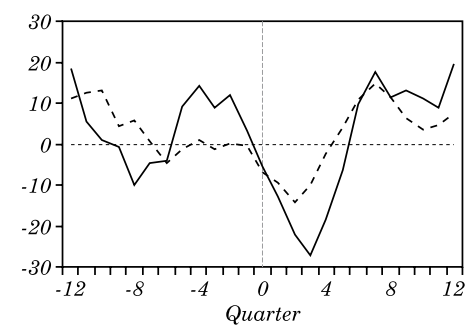

Advanced countries

Source: Authors' calculations.

a. The solid line denotes the median of all observations for emerging market countries, while the dashed line corresponds to the median of all observations for advanced countries. Zero is the quarter after which the recssion begins (the peak in the level of output). 
There are also some differences in the behavior of trade and financial variables. In emerging markets, the growth rate of exports slows down sharply, but still stays above that of advanced countries after the beginning of recessions. In contrast, the import sector goes through a much sharper adjustment in emerging markets than in advanced countries, and it actually registers several quarters of negative growth. Credit slows down in advanced countries during recessions, but it contracts in emerging markets. Finally, equity prices tend to exhibit a much sharper decline in emerging markets than in advanced countries during recessions. Almost all macroeconomic and financial variables thus exhibit much sharper adjustments during recessions in emerging markets than in advanced countries.

\subsection{Downside of Fluctuations in Financial Markets}

Next, we provide summary statistics about the episodes of credit contractions and equity price declines in emerging markets (table 3). In terms of duration, episodes of credit contractions last longer than recessions, slightly less than seven quarters. Equity price declines are slightly shorter, but they are also longer than the typical recession, with a median duration of six quarters. As we noted above, a credit crunch (equity price bust) is defined as a peak-to-trough contraction (decline) in credit (equity) that falls within the top quartile of all credit contractions (equity price declines). In terms of amplitude, a typical credit crunch is associated with a decline in credit of almost 50 percent, while a credit contraction episode leads to about a 12 percent decline. An episode of equity price decline (bust) tends to result in a fall of 37 percent (70 percent) in equity prices. Credit crunches and equity price busts not only have greater amplitudes-by definition-but they also last longer than other credit contractions and equity price declines do, eleven versus five quarters and nine versus five quarters, respectively.

Although the duration of credit crunches in advanced countries is longer than that in emerging countries, crunches in advanced countries are much less intense than those in emerging markets. The periods of equity busts in advanced countries last as long as those in emerging markets, but they lead to smaller declines in equity valuations. Consistent with the highly volatile nature of credit and equity markets in emerging economies, the slopes of credit contractions and equity price declines in these countries are much larger than those in advanced countries. 


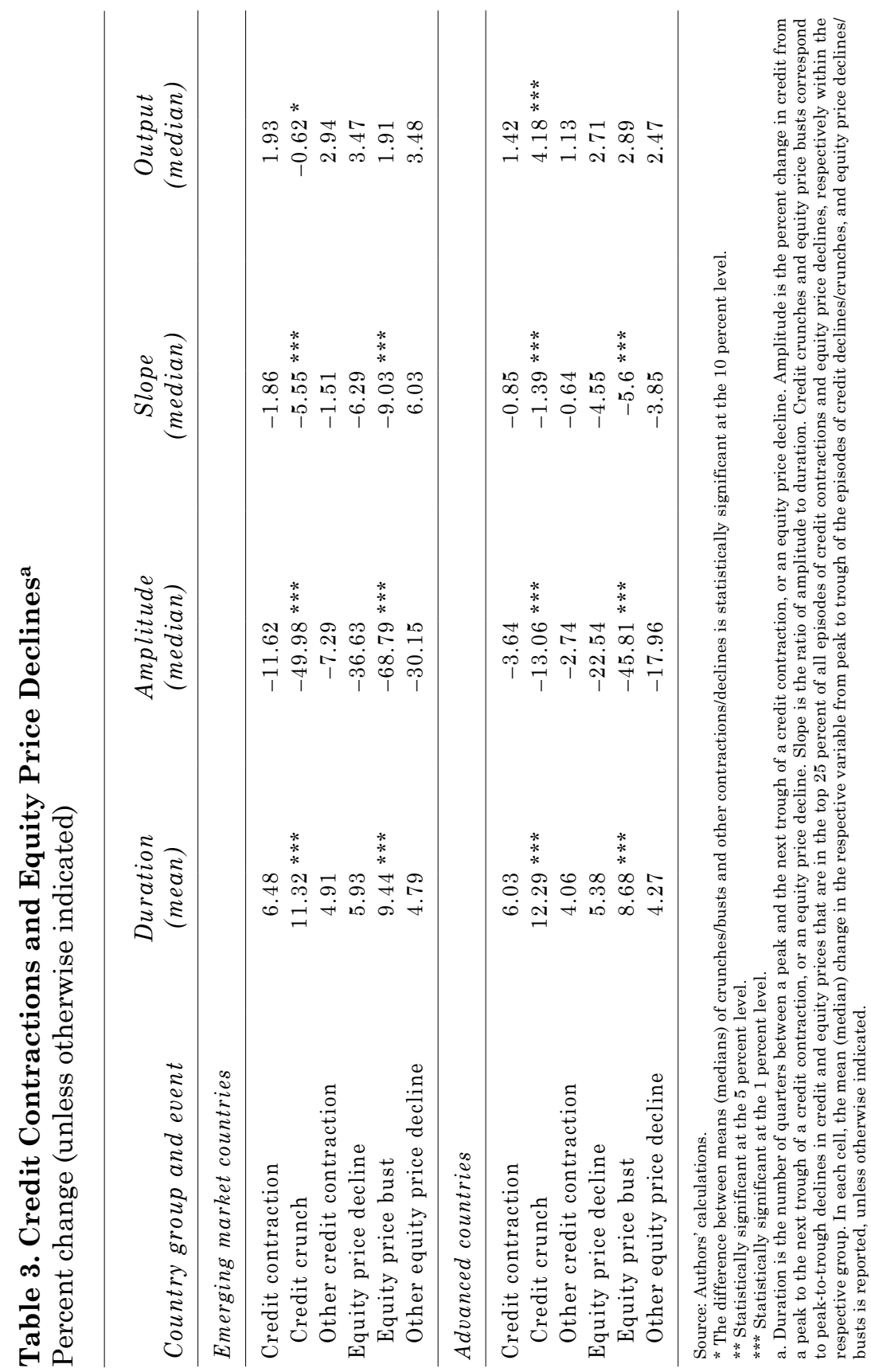


Episodes of credit contractions and equity price declines are typically not associated with a drop in output. However, they do coincide with a significant decline in activity when they take the form of a credit crunch. For example, output typically falls around 0.6 percent over the period of a crunch episode in emerging markets, while even during equity busts output registers positive growth. Compared to emerging markets, financial market disruptions in advanced countries are associated with less adverse outcomes in the real economy.

\subsection{Recessions and Financial Disruptions}

What are the implications of recessions in emerging markets when they are accompanied by (severe) credit crunches, equity price busts, or financial crises? We now answer this question with a set of summary statistics reported in table 4 . When recessions are accompanied with disruptions in financial markets, they tend to be longer and deeper. To provide a sense of their distribution, we examine separately the features of recessions coinciding with severe episodes, that is, the top 12.5 percent of all financial market disruptions. We also provide the summary statistics for these types of events in advanced countries to allow for comparisons.

Output declines significantly more in recessions associated with a credit crunch than in other recessions, 8.5 percent versus 4.7 percent. The cumulative output loss in recessions associated with (severe) crunches is often larger than in recessions without crunches. There are a number of statistically significant differences between recessions coinciding with equity price busts and those without. While differences are not noticeable in duration, they are in some other aspects of recessions. In particular, declines in output (and corresponding cumulative losses) are typically much greater in recessions with busts, 6.8 (13.6) percent versus 3.3 (4.6) percent without busts.

With respect to their duration, recessions with financial crises are generally as long as those associated with credit crunches and equity price busts. In terms of their amplitude, recessions associated with credit crunches appear to be more costly than recessions with equity price busts, while recessions associated with financial crises are about as costly. If we use the cumulative loss measure as the relevant metric, then recessions associated with equity busts are slightly more costly than those associated with credit crunches (13.6 


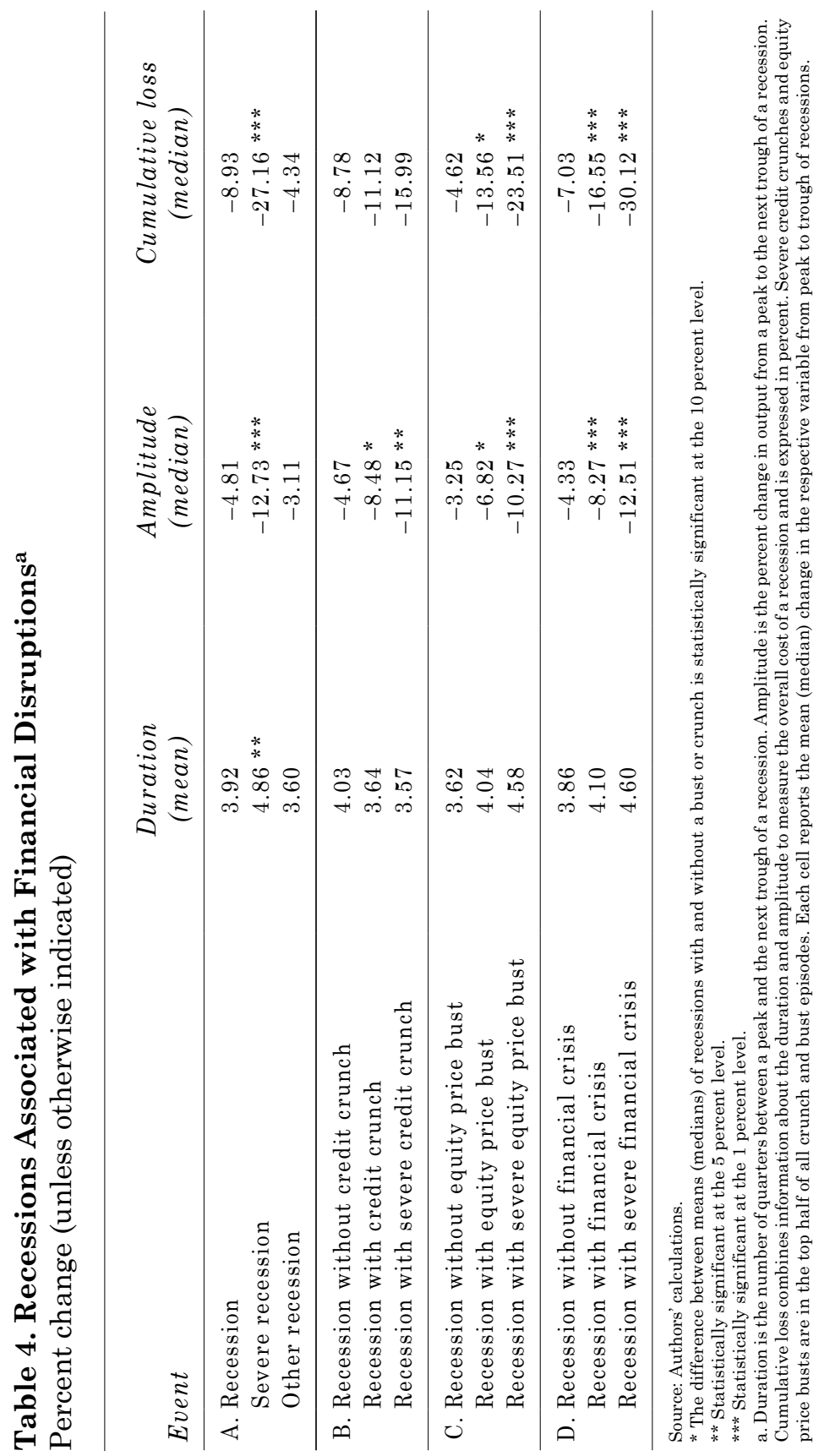


percent versus 11.1 percent). The cumulative losses stemming from the recessions associated with crises are typically larger than those in recessions accompanied with either credit crunches or equity price busts. These differences are even starker for the recessions associated with severe credit crunches or equity price busts and for the severe recessions accompanied by financial crises.

Recessions associated with equity price busts are much more costly events than those without equity busts for the sample of emerging markets. This is unlike the results for advanced countries. For example, Claessens, Kose, and Terrones (2009) report that although recessions associated with equity price busts tend to be longer and deeper than those without equity busts in advanced countries, many of these differences are not statistically significant. This might reflect the fact that the link between equity price busts and developments in the real economy in advanced countries are weaker compared to that of credit crunches. In emerging market economies, gyrations in equity markets are often associated with large swings in the direction and volume of capital flows, which suggests that recessions associated with equity price busts probably coincide with severe disruptions in the real economy as well as the balance of payments.

\section{Recessions and Financial Disruptions: The Case of Chile}

In light of the lessons from our broader analysis of the episodes of recessions and financial disruptions in emerging markets, we now turn our attention to the Chilean case. The broad overview of these episodes generally paints a grim picture about their adverse impact on the dynamics of growth and stability in emerging economies, especially when contrasted with the experiences of advanced countries. Some emerging markets have been quite successful, however, in either largely avoiding recessions and financial disruptions or managing their harmful effects when they nevertheless occur. These countries have been able to deliver persistently high growth while maintaining a stable economic environment. Chile occupies a special place among this elite group of emerging markets, but it has experienced its own recessions and financial market disruptions, as well. How do the episodes in Chile compare with those in other emerging markets?

We first present our findings with respect to the main properties of Chilean recessions. We then discuss how the dynamics of recessions in Chile compare with those in other emerging market economies. We 
conclude the section with a brief summary of the episodes of credit contractions and equity market declines in Chile.

\subsection{A Brief Review of the Chilean Recessions}

Using quarterly data, we identify three recessions over the period from 1980:1 to 2007:4 in Chile: 1981:3 to 1982:4, 1990:1 to 1990:3, and 1998:2 to 1999:1 (table 5 and figure 5). The longest and

\section{Figure 5. Recessions in Chile: Output and Industrial} Production $^{\text {a }}$

\section{A. Output}

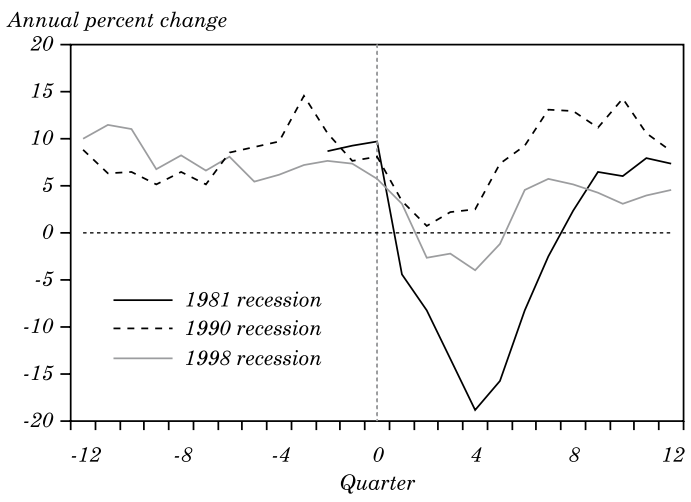

B. Industrial production

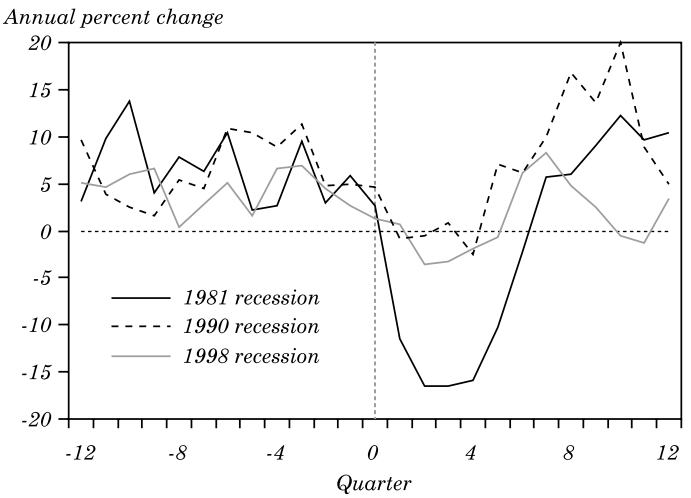

Source: Authors' calculations.

a. Zero is the quarter after which a recession begins (the peak in the level of output). 


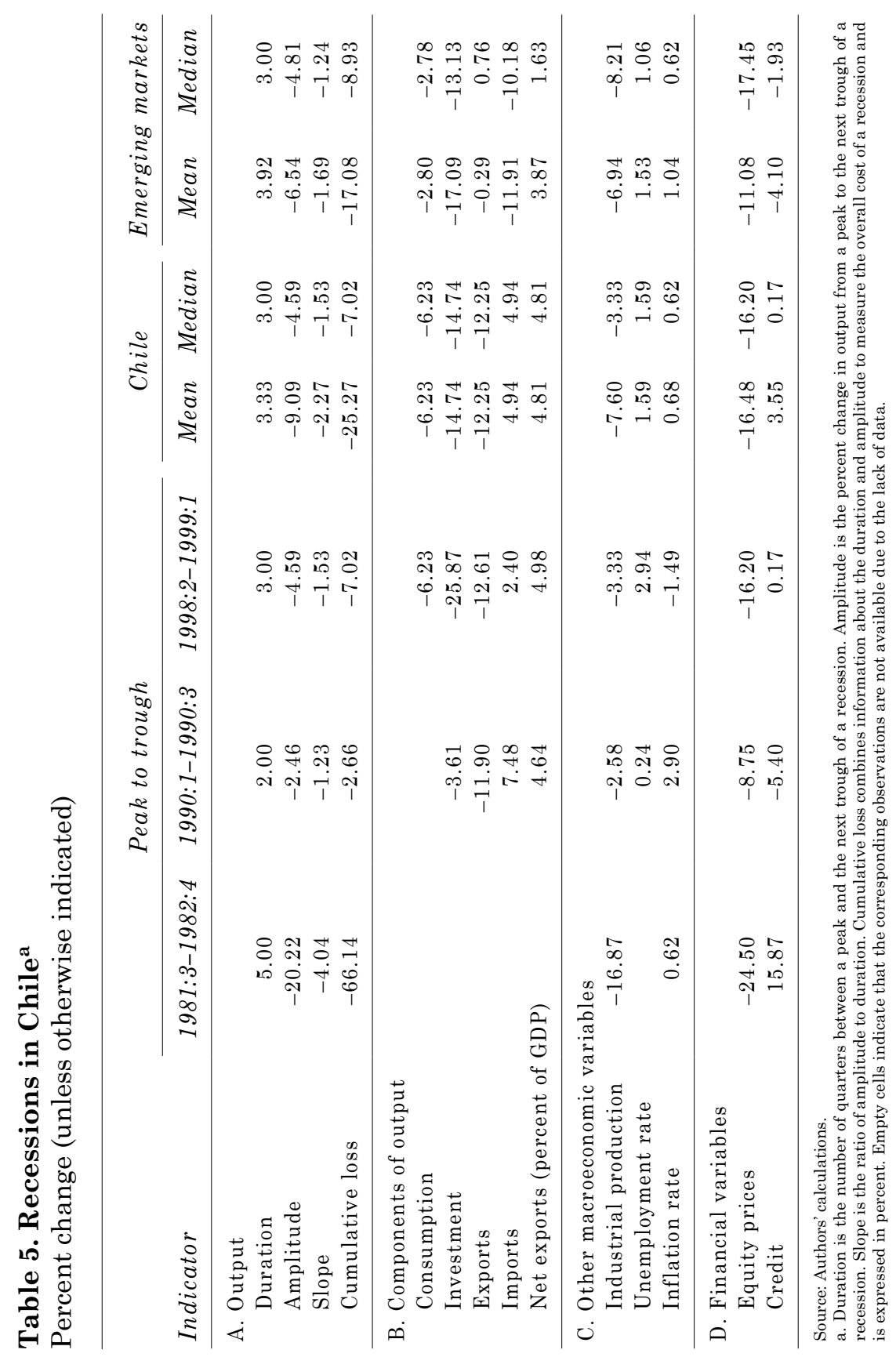


deepest recession in Chile took place in the early 1980s and resulted in a significant decline in output over five quarters. The recession in the early 1990s was the shortest and mildest one, with decline in output of about 2.5 percent over two quarters. The recession in the late 1990s lasted three quarters and led to an output decline of roughly 4.6 percent.

The number and the dates of the Chilean recessions we document are mostly consistent with those in other studies using quarterly data. For example, Calderón and Fuentes (2006) also report that the Chilean economy witnessed three recessions over their sample of 1980-2005. Our findings with respect to the dates of recessions are also similar to some of the turning points identified in MejíaReyes $(1999,2004){ }^{13}$

Although the use of annual data can allow one to study the evolution of Chilean recessions over a longer period, this is not advisable for at least a couple of reasons. First, by construction, the use of annual data makes it impossible to identify recessions that are shorter than four quarters, unless these recessions are characterized by large enough quarterly declines in output that in turn lead to an outright contraction in annual series. In the case of Chile, for example, it is not possible to detect the early 1990s recession in annual data. In our broader sample of emerging markets, the number of recessions falls to 67 (from 84) if we simply define recessions as contractions in yearly output. Second, the use of annual data can distort the dating of recessions, even if the annual growth rate is negative in a particular year. ${ }^{14}$

Even with quarterly data, differences can arise because of varying data sources and frequency of data. Our main data source for the quarterly series of the Chilean macroeconomic and financial variables is the IMF's IFS. We compare our cyclical turning points with those computed using data series from other sources, such as the Global Data Source and the Central Bank of Chile. We conclude that our findings are robust to the use of these alternative data sources. We

13. The former study uses annual data and documents three recessions (1953-56, 1971-76, and 1981-83) over the period 1950-95. The latter study considers the turning points in the monthly industrial (or manufacturing) production index between 1960 and 2001 and identifies four recession episodes: 1971.9 to $1975.8,1980.12$ to 1982.10 , 1984.6 to 1985.5 , and 1989.12 to 1990.5 .

14. For instance, the third recession in Chile begins in 1998:2 and ends in 1999:1. Since the growth rate of output is positive in 1998 and negative in 1999 in annual series, the date of the recession is incorrectly identified as 1999 using the annual data. 
also check whether there is contraction not only in GDP, but also in other main indicators of activity, including industrial production, consumption, and investment, during the recessionary periods we identified. All of these variables also register negative growth rates during the recessions we determined, indicating that the dates we identify are true recessions reflecting significant decline in activity spread across multiple segments of the Chilean economy. ${ }^{15}$

Recessions can be driven by a number of factors. Moreover, it can be hard to identify conclusively the most important causes for specific recession episodes, as the voluminous literature on the sources of business cycles has made clear. This observation also applies to the recessions experienced by Chile. Nevertheless, a review of the individual recession episodes along with the related literature can help clarify what factors may have been at play during these events.

The first Chilean recession we identify (1981:3-1982:4) coincided with the 1982 global recession, in which the world per capita GDP fell by around 1 percent (see Kose, Loungani, and Terrones, 2009). The recession in Chile resulted in a significant decline in both output (20 percent) and industrial production (17 percent). This episode was also accompanied by an equity price bust and a disruption in credit markets. Although credit did expand over the course of the recession, it began contracting in 1982:2, as a major financial crisis occurred during that year.

Reflecting the simultaneously ongoing global recession, decline in demand was an important factor during the 1981-82 recession. This meant a significant fall in demand for Chile's exports, given that the economy is dependent on commodity exports. ${ }^{16}$ There were other external factors, as well: the tight monetary policies in several advanced economies, the rapid increase in oil prices, and the debt crisis experienced by a number of Latin American countries

15. Some other studies examine the stylized facts of the Chilean business cycles using filtered time series. For example, Belaisch and Soto (1998) study the characteristics of business cycles in Chile for 1986-97 using the HP-filtered data. They report that the average business cycle in Chile lasts three years, half of it in the recession phase, and the other half in the expansion phase. Their findings indicate that the amplitude of the cycle is about 3 percent. Given the time-varying nature of the trends computed by the HP filter, it is hard to contrast their findings with those coming from the studies employing the classical methodology, such as ours.

16. Copper exports constitute a significant source of revenue for the Chilean economy. Spilimbergo (1999) and Caballero (2001) find a strong association between the price of copper and business cycles in Chile, while De Gregorio (2009) claims that Chile does not share the curse of rich natural resources that often stunts the long-term economic growth in commodity-dependent countries. 
reduced the supply of external financing. Indeed, net private capital inflows to Chile registered a decline during this period (see IMF, 1983). Franken, Le Fort, and Parrado (2005) consequently argue that the recession resulted from a sudden stop in capital inflows coinciding with a deterioration of the terms of trade, a jump in the world interest rates, and the sharp adjustment in the real exchange rate.

As documented in the literature, there were also various Chilespecific factors associated with this episode. First, in addition to the problems in international capital markets, the Chilean financial system was under stress as banks had taken excessive risk, leading to a deterioration of their loan portfolios and eventually resulting in a full-blown banking crisis (see Larraín, 1989; Barandiaran and Hernández, 1999). Second, as Edwards (1983) notes, the fixed exchange rate regime combined with the rigid wage rate policy precluded any downward adjustment in real wages. ${ }^{17}$

The 1990:1-1990:3 recession also coincided with a worldwide slowdown in activity, ahead of the 1991 global recession. The global recession reflected problems in various parts of the world: difficulties in the U.S. saving and loan industry, banking crises in several Scandinavian economies, an exchange rate crisis in a large number of European countries, the challenges faced by East European transition economies, and the uncertainty stemming from the Gulf War and the subsequent increase in the oil price. In Chile, the recession meant declines in investment, exports, and industrial production and a slight increase in the unemployment rate. The Chilean financial markets went through a rough period as credit fell by 5 percent and the equity market declined by 9 percent. ${ }^{18}$

After the brief recession of the early 1990s, Chile registered strong economic growth until 1998. In fact, growth averaged around 7 percent per year and per capita income doubled over the period

17. For an extensive discussion of the developments prior to this episode and the associated banking crisis, see IMF (1982), Edwards (1983), Barandiaran and Hernández (1999), and Franken, Le Fort, and Parrado (2005). Franken, Le Fort, and Parrado (2005) argue that the rapid increase in bank credit in the late 1970s and the early 1980s resulted in a severe deterioration of the quality of the loan portfolio and increased exposure to exchange rate movements. In a related paper, Barajas, Luna, and Restrepo (2007) investigate macroeconomic fluctuations and bank behavior in Chile between 1989 and 2006 .

18. As De Gregorio (2009) notes, there was political uncertainty in the early 1990s, as it was a period of transition to democracy after the 1989 elections following 16 years of military regime. 
1985-98. ${ }^{19}$ The recession of $1998: 2$ to $1999: 1$ marked the end of Chile's "golden period" of growth, however (see De Gregorio, 2004). The main driving forces behind the 1998-99 recession were external developments, notably the Asian crisis in 1997 and the Russian crisis in 1998. The accompanying decline in copper prices led to a significant deterioration of Chile's terms of trade and a substantial decline in exports. The recession resulted in a GDP contraction of 4.6 percent, along with sharp reductions in consumption and investment. Industrial production contracted, and the unemployment rate increased. The equity market registered a substantial decline. Credit growth was muted over the course of the recession, in part because of an increase in the policy rates to stem the depreciation of the currency. ${ }^{20}$

The brief review we present here thus consistently emphasizes the importance of external, and to a lesser degree domestic, factors in explaining the recessions in Chile. This confirms the findings of some earlier studies employing different methodologies to study the determinants of macroeconomic fluctuations for Chile. Franken, Le Fort, and Parrado (2005), for example, use a vector autoregression model over the 1950-2003 period to examine how Chilean business cycles respond to various shocks. They report that external shocks constitute the main source of business cycle fluctuations in Chile. In a related paper, Medina and Soto (2007) analyze the sources of business cycle fluctuations in Chile for the period 1987-2005 using a dynamic stochastic general equilibrium model. They conclude that both foreign and domestic supply shocks play important roles in accounting for output fluctuations, whereas domestic demand shocks and terms-of-trade shocks tend to have relatively minor effects.

We conclude this subsection with a brief look at how the Chilean recessions compare with those in other emerging market economies. In terms of the number of episodes, Chile witnessed only three

19. For a detailed analysis of the "golden period" of growth in Chile, see Gallego and Loayza (2002). They document that a significant part of growth was explained by the growth of total factor productivity after 1985, whereas before 1985, it was mostly due to labor growth.

20. Franken, Le Fort, and Parrado (2005) argue that this recession could have been avoided if monetary policy did not overreact to limit the currency depreciation by narrowing the exchange rate band. At the end of the 1998, the copper price started to rise again, and with expansionary monetary and fiscal policies, the Chilean economy started to recover (IMF, 2000). Simonovska and Soderling (2008) examine the sources of business cycles in Chile using a dynamic stochastic general equilibrium (DSGE) model with time-varying frictions over 1998-2007. They conclude that changes in productivity and labor markets played important roles in explaining the 1998-99 crisis. 
recessions, whereas a typical emerging economy experienced four over the sample period. However, the features of a typical Chilean recession are quite similar to those of emerging markets, as the median amplitude of the three recessions is about 4.6 percent and the median duration about three quarters (figure 6). The median decline in industrial production during the Chilean recessions, however, is roughly three times smaller than that in recessions in other emerging markets. The recession of the early 1980s in Chile was a severe one, though, and it was deeper than the typical severe recession in emerging market economies. Nevertheless, if one focuses on the last two recessions over the period 1980-2007, it is obvious that the Chilean economy experienced relatively milder episodes than the typical emerging market in our sample.

\subsection{Dynamics of Recessions in Chile}

We next examine how various macroeconomic and financial variables behave around recessions in Chile and how the dynamics of Chilean recessions compare with those in other emerging market economies. We focus on patterns in year-on-year growth in each variable for a six-year window-12 quarters before and 12 quarters after a peak (figure 7). We focus on year-on-year changes since quarter-to-quarter changes can be quite volatile. For comparison

\section{Figure 6. Recessions and Financial Disruptions: Chile and Emerging Market Countries ${ }^{a}$}

\section{A. Duration}

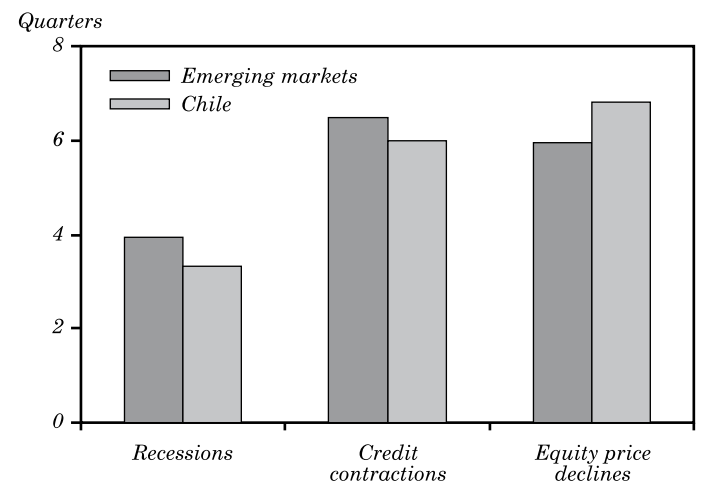


Figure 6. (continued)

\author{
B. Amplitude
}

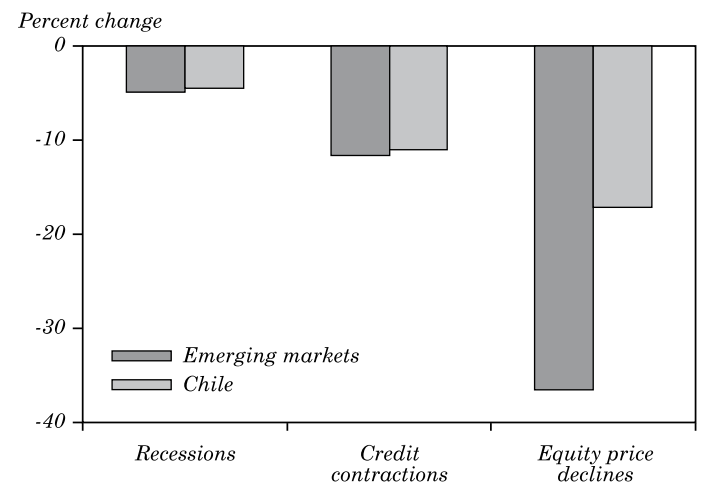

C. Industrial production

Percent change

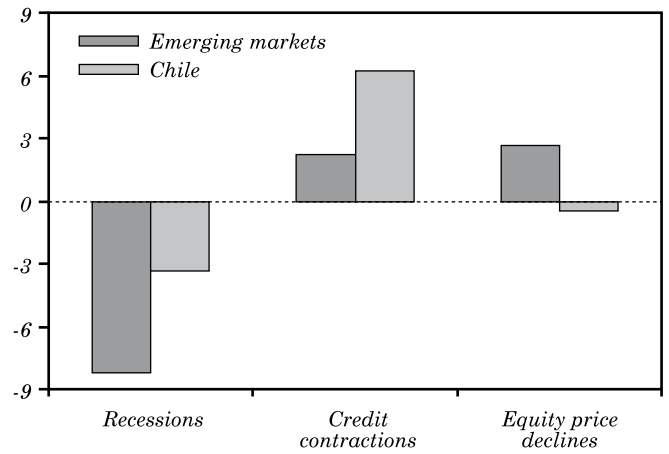

Source: Authors' calculations.

a. Duration is the mean of the number of quarters in a recession, credit contraction, or equity price decline. Amplitude is the median change in output, credit, and equity prices during recessions, credit contractions, and equity price declines, respectively. The bottom panel presents the median change in industrial production during recessions, credit contractions, and equity price declines.

purposes, we include the median growth rates of the three recessions in Chile and also those for all emerging markets, along with the top and bottom quartiles. The severe recessions are in the bottom quartile, consistent with our earlier definition of these episodes.

The evolution of output growth in a typical recession in Chile is no different than the typical recession in other emerging markets. Following the peak at date 0 , output tends to register negative 
Figure 7. Recession Dynamics in Emerging Market Countries and Chile ${ }^{a}$

Annual percent change

\section{A. Output}

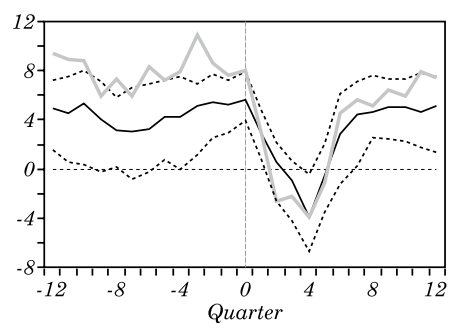

C. Net exports / GDP

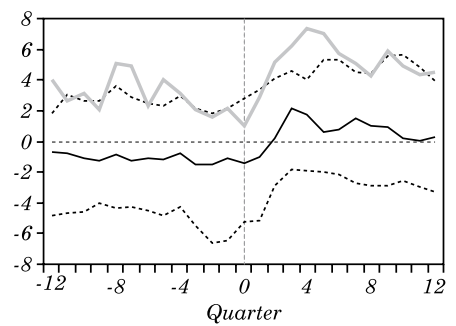

E. Private credit

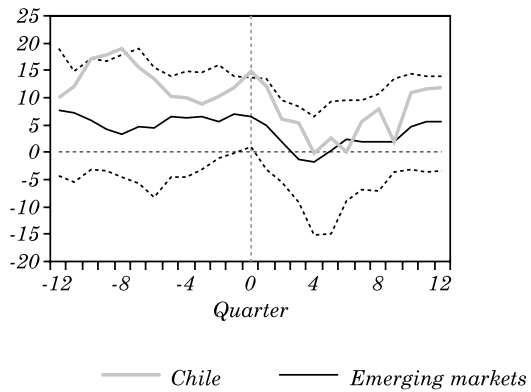

B. Total investment

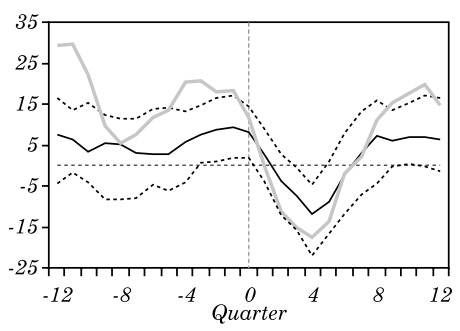

D. Industrial production

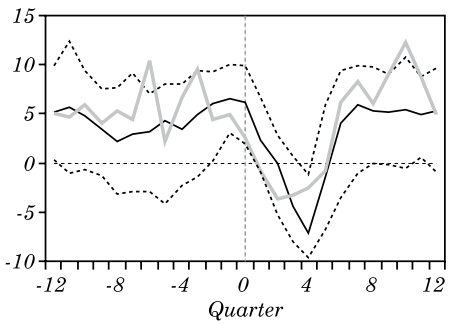

F. Equity prices

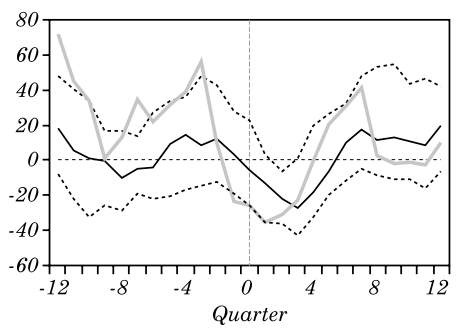

Upper and lower quartiles

Source: Authors' calculations.

a. The gray line denotes the median of all Chilean observations. The solid line represents the median of all observations for emerging market countries, and the dotted lines correspond to the upper and lower quartiles. Zero is the quarter after which a recession begins (the peak in the level of output). The ratio of net exports to GDP is the level in percent. 
annual growth after two quarters, falling to -4 percent four quarters after the peak. Relative to the typical emerging market recession, however, investment registers a much sharper decline in the first year of a recession in Chile. Moreover, the contraction in investment is deeper than that in output and lasts longer. In severe recessions, it can take up to three years for investment growth to recover. Industrial production in Chile also typically registers a sharp decline, although the contraction is milder than is typical in emerging markets.

Net exports improve sharply in the first year of a typical Chilean recession. The bounce in net exports in Chile is much larger than that observed in emerging market economies. The growth rate of exports slows but often stays positive in emerging markets. Import growth, however, often falls with the beginning of the recession and can decline to -10 percent in the first year of a recession.

Recessions in Chile appear to feature more significant declines in credit growth and equity prices than those in emerging market economies. In a typical emerging market recession, credit growth slows down sharply at the beginning and then contracts by about 2 percent in the first year. The growth rate of credit typically does not return to prerecession growth rates for a number of quarters. Recessions in Chile and other emerging markets are often preceded by slowdowns in the growth rates of equity prices. In the first year of a typical recession, equity prices decline on a year-to-year basis by roughly 30 percent. However, there is also evidence that equity prices are forward looking, as they often start registering positive growth ahead of the trough of the business cycle.

\subsection{Financial Disruptions in Chile}

Next, we provide summary statistics regarding the episodes of credit contractions and equity price declines in Chile, again comparing them with those in other emerging markets (tables 6 and 7). We identify three credit contraction episodes in Chile. The first and third of these episodes coincide with the early 1980s and the early 1990s recessions. The first one is also accompanied by a financial crisis. In terms of duration, a typical credit contraction episode in Chile lasts two times longer than a typical recession, at six quarters versus three quarters. In terms of amplitude, a typical credit decline in Chile is about 11 percent. 


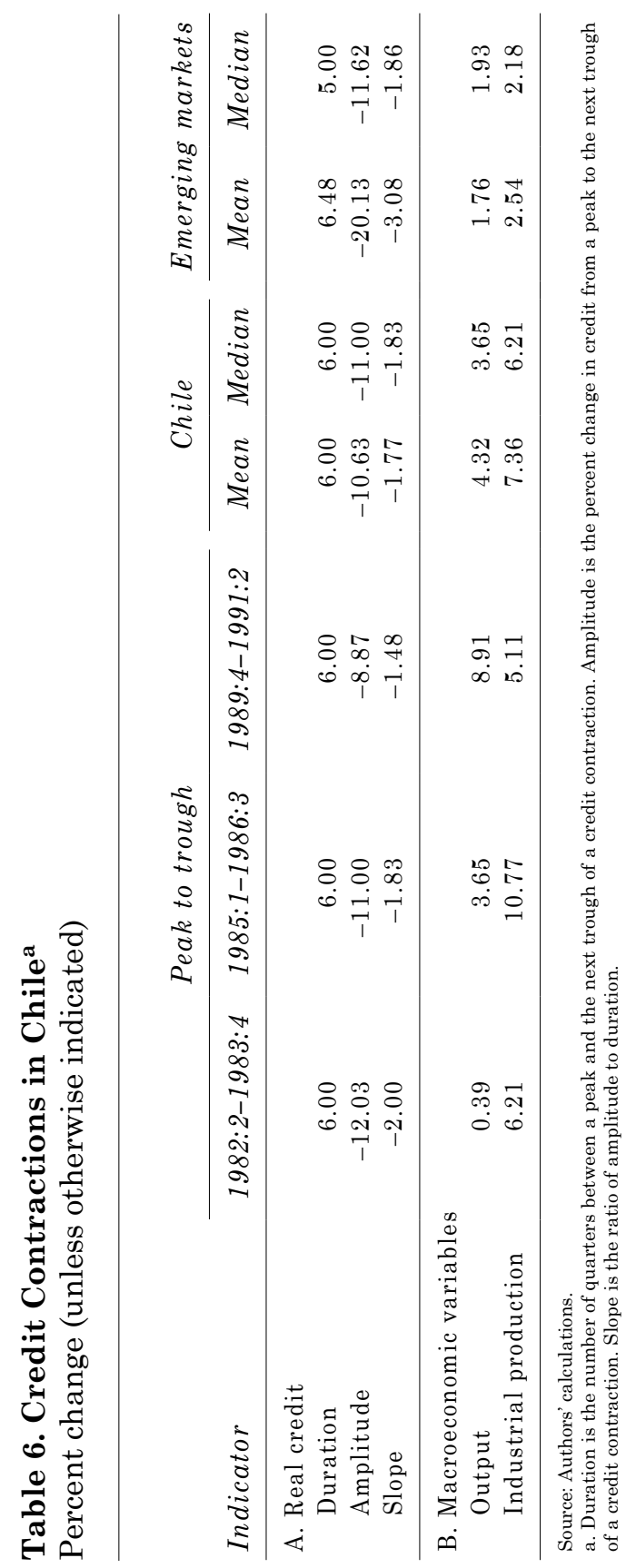




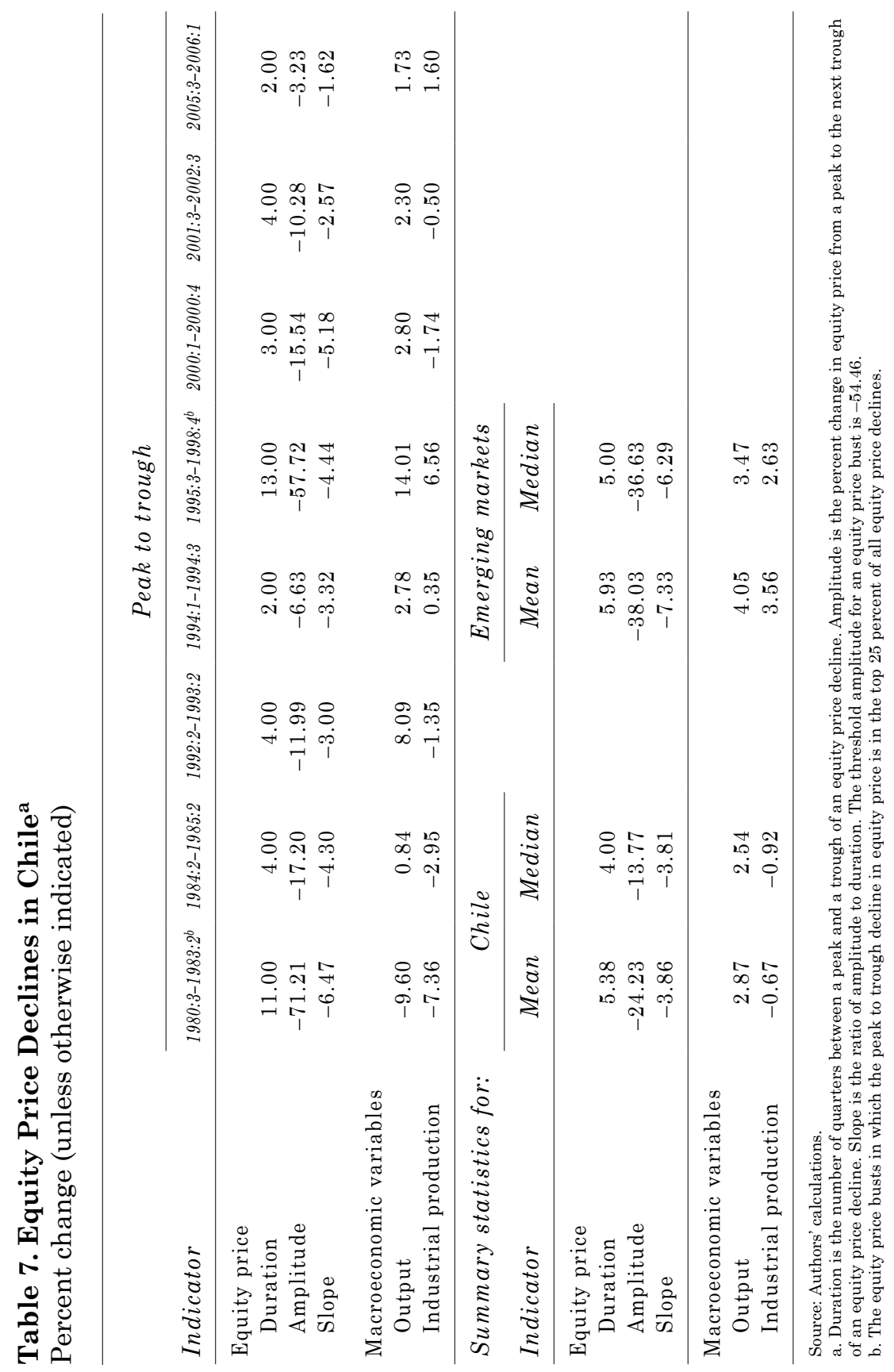


The growth of economic activity, measured by output or industrial production, slows down, especially early on in a credit contraction episode, but the level of activity is typically higher at the end of these episodes than at the beginning. The increase in output over the course of a credit contraction is not surprising since these episodes do not always fully overlap with recessions and last twice as long as recessions. Although Chile did not experience a credit crunch episode during the period we examine, the typical credit decline episode in Chile was quite similar to the emerging market average in terms of duration, amplitude, and slope (see figure 6). However, the Chilean economy tends to perform better than the typical emerging market during credit contractions, as evidenced by much higher growth rates of output and industrial production.

In terms of equity price declines, Chile experienced eight episodes over the period 1980-2007, slightly more than other emerging market economies (six). Some of the emerging market economies, however, have shorter equity price series than Chile. The declines last between two and 13 quarters in Chile. The episodes of equity price declines are typically shorter than credit contractions, but still slightly longer than recessions. A typical decline episode in Chile leads to a fall of around 14 percent in equity prices, which is less than half the amplitude of a decline in such episodes in emerging markets.

Chile witnessed two equity busts over the sample period under consideration. The first one occurred during the recession of the early 1980 s and resulted in a decline in equity prices of around 70 percent. The second one was in the mid-1990s and was associated with the Asian crisis. Equity price busts not only have greater amplitudes (by definition), but also last longer than credit contractions and equity price declines. While output in Chile rarely registered negative growth over the course of a typical equity price decline, industrial production tends to fall in most episodes. The episodes of equity price declines in Chile are more muted relative to those in other emerging markets, but they are associated with somewhat weaker growth, as well.

\section{Conclusions}

We provide a brief overview of the macroeconomic implications of recessions and financial disruptions in emerging market economies. To undertake this exercise, we utilize a rich data set of business and financial cycles based on reasonably long quarterly time series of multiple measures of real and financial activity. Our data set covers 
a large number of advanced and emerging market countries, which allows us to compare the features of these episodes in the two groups. Although our objective is to present an overview, we also address three specific questions.

First, what are the main features of recessions and financial disruptions in emerging markets? A typical emerging market country experiences about four recessions. The fraction of time spent in recession is typically 50 percent longer for Latin American emerging economies than for Asian emerging markets. In the case of advanced countries, the same statistic is about 13 percent, on average, which is much less than for emerging markets. Output declines by about 5 percent in a recession in emerging market economies, with substantial differences across regions. For example, the typical recession in Latin American emerging markets is two times more costly than in their Asian counterparts.

Recessions in emerging markets tend to be deeper than those in advanced countries: the amplitude of a typical emerging country recession is about three times larger than that of an advanced country. Our findings suggest that the typical recession in emerging economies is equivalent to a severe recession in advanced countries in terms of its amplitude and cumulative loss. The dynamics of adjustment around recessions in emerging markets also differ substantially from those in advanced countries. These findings confirm the results of a number of earlier studies about the more volatile nature of business cycles in emerging markets.

Financial market disruptions in emerging markets are also more severe than those in advanced countries. Although credit crunches in advanced countries last longer than those in emerging countries, crunches in advanced countries are much less intense. The periods of equity busts in advanced countries last as long as those in emerging markets, but they lead to smaller declines in equity valuations. The slopes of credit contractions and equity price declines in emerging markets are much larger than those in advanced countries, which highlights the highly volatile nature of credit and equity markets in these economies.

Second, how synchronized are these events across emerging markets? Our results suggest that recessions in emerging markets are highly synchronized events. Financial disruptions can be synchronous, as well. In particular, equity prices exhibit the highest degree of synchronization, reflecting the extensive integration of stock markets around the world. Credit contractions are somewhat less 
synchronized across countries, but still there are eight years in which more than 40 percent of countries experience credit contractions. Recessions tend to coincide most closely with contractions in domestic credit in emerging market economies and somewhat less with declines in equity prices. These findings are similar to the earlier results reported for advanced economies.

Third, how does the coincidence between recessions and financial disruptions affect macroeconomic outcomes? When recessions are accompanied by disruptions in financial markets, they tend to be longer and deeper. In particular, recessions associated with credit crunches appear to be more costly in terms of amplitude than recessions with equity price busts, while recessions associated with financial crises are about as costly.

In light of these general observations, we also ask whether the Chilean recessions and financial disruptions are different than those of other emerging markets. Chile witnessed three recessions in our sample period, whereas a typical emerging economy experienced four. After taking into account the small number of observations we have for Chile, we reach three tentative conclusions. First, the features of a typical Chilean recession are quite similar to those of emerging markets. Second, the dynamics of output around recessions in Chile are also similar to other emerging markets. However, if we exclude the very severe recession of the early 1980s and simply focus on the last two recessions prior to 2008, the Chilean economy appears to experience relatively milder episodes than the typical emerging market in our sample. Third, while the episodes of credit declines in Chile are quite similar to those in emerging markets in terms of their duration, amplitude, and slope, the Chilean economy tends to perform better than its peers during such episodes. In contrast to the credit contractions, the episodes of equity price declines in Chile are more muted relative to those in other emerging markets, but they are associated with somewhat weaker growth.

Consistent with its historical record presented here, Chile performed better than most other emerging market economies during the 2008-09 global financial crisis. Recent studies point to a number of factors that can explain Chile's performance over the past two years. ${ }^{21}$ First, the macroeconomic and financial policies

21. De Gregorio (2009), IMF (2008), Ocampo (2009), García (2009), Jara, Moreno, and Tovar (2009), and Blanchard, Faruqee, and Das (2010) examine various aspects of the Chile's macroeconomic performance during the global financial crisis. 
employed by Chile were sound and effective. For example, its fiscal policy was well-positioned to stimulate the economy, and its financial system was well-capitalized under rigorous supervision. Second, the commodity boom prior to the crisis resulted in large dividends for Chile. Third, exchange rate policies were instrumental in stabilizing foreign capital movements.

Our preliminary investigation has just scratched the surface of the complex linkages between recessions and financial disruptions in emerging market economies. There are a number of issues to be explored in future research. One additional approach to shed more light on these linkages would be to use individual firm data for a large sample of countries. Another fruitful area is to examine the nature of underlying shocks leading to differences in the features of recessions and financial disruptions in emerging markets and advanced countries. 


\section{ReFerences}

Aghion, P., P. Bacchetta, and A. Banerjee. 2001. "Currency Crises and Monetary Policy in an Economy with Credit Constraints." European Economic Review 45(7): 1121-50.

Artis, M.J., Z.G. Kontolemis, and D.R. Osborn. 1997. "Business Cycles for G7 and European Countries." Journal of Business 70(2): 249-79.

Barajas, A., L. Luna, and J.E. Restrepo. 2007. "Macroeconomic Fluctuations and Bank Behavior in Chile." Working paper 436. Santiago: Central Bank of Chile.

Barandiaran, E. and L. Hernández. 1999. "Origins and Resolutions of a Banking Crisis: Chile 1982-86.” Working paper 57. Santiago: Central Bank of Chile.

Belaisch, A. and C. Soto. 1998. "Empirical Regularities of Chilean Business Cycles.” Working paper 41. Santiago: Central Bank of Chile.

Bernanke, B.S. and M. Gertler. 1989. "Agency Costs, Net Worth, and Business Fluctuations." American Economic Review 79(1): 14-31.

Bernanke, B.S., M. Gertler, and S. Gilchrist. 1996. "The Financial Accelerator and the Flight to Quality." Review of Economics and Statistics 78(1): 1-15.

- 1999. "The Financial Accelerator in a Quantitative Business Cycle Framework." In Handbook of Macroeconomics, vol. 1C, edited by J.B. Taylor and M. Woodford, pp. 1341-93. Amsterdam: Elsevier.

Bernanke, B.S. and C.S. Lown. 1991. "The Credit Crunch." Brookings Papers on Economic Activity 2: 205-47.

Blanchard, O., H. Faruqee, and M. Das. 2010. "The Initial Impact of the Crisis on Emerging Market Countries." Brookings Papers on Economic Activity 1: 263-307.

Borio, C., C. Furfine, and P. Lowe. 2001. "Procyclicality of Financial Systems and Financial Stability." BIS Papers 1. Basel: Bank for International Settlements.

Bry, G. and C. Boschan. 1971. "Cyclical Analysis of Time Series: Selected Procedures and Computer Programs." Cambridge, Mass.: National Bureau of Economic Research.

Burns, A.F. and W.C. Mitchell. 1946. Measuring Business Cycles. Cambridge, Mass.: National Bureau of Economic Research.

Caballero, R.J. 2001. "Macroeconomic Volatility in Latin America: A View and Three Case Studies.” Estudios de Economía 28(1): 5-52. 
Caballero, R.J. and A. Krishnamurthy. 1998. "Emerging Market Crises: An Asset Markets Perspective." Working paper 98-18. Cambridge, Mass.: Massachusetts Institute of Technology (MIT), Department of Economics.

Calderón, C. and R. Fuentes. 2006. "Characterizing the Business Cycles of Emerging Economies." London: Centre for Economic Policy Research.

Céspedes, L.F., R. Chang, and A. Velasco. 2004. "Balance Sheets and Exchange Rate Policy." American Economic Review 94(4): 1183-93.

Chang, R., L. Kaltani, and N.V. Loayza. 2009. "Openness Can Be Good for Growth: The Role of Policy Complementarities." Journal of Development Economics 90(1): 33-49.

Chari, V.V., L. Christiano, and P.J. Kehoe. 2008. "Facts and Myths about the Financial Crisis of 2008." Working paper 666. Federal Reserve Bank of Minneapolis, Research Department.

Claessens, S., M.A. Kose, and M.E. Terrones. 2009. "What Happens during Recessions, Crunches, and Busts?" Economic Policy 24 (October): 653-700.

- forthcoming. "Business and Financial Cycles in Emerging Markets." Working paper. Washington: International Monetary Fund.

Cohen-Cole, E., B. Duygan-Bump, J. Fillat, and J. Montoriol-Garriga. 2008. "Looking behind the Aggregates: A Reply to "Facts and Myths about the Financial Crisis of 2008." Working paper QAU08-5. Federal Reserve Bank of Boston.

De Gregorio, J. 2004. "Economic Growth in Chile: Evidence, Sources, and Prospects." Working paper 298. Santiago: Central Bank of Chile.

- 2009. "Economic Growth in Chile and Copper." Speech presented at the CESCO conference "1984-2009: 25 años de la industria del cobre y su impacto en Chile." Santiago, 1 September.

Du Plessis, S. 2006. "Business Cycles in Emerging Market Economies: A New View of the Stylized Facts." Working paper 02/2006. Stellenbosch University, Department of Economics.

Edwards, S. 1983. "Stabilization with Liberalization: An Evaluation of Ten Years of Chile's Experiment with Free Market Policies, 1973-1983.” Working paper 309. University of California at Los Angeles, Department of Economics.

Fisher, I. 1933. "The Debt-Deflation Theory of Great Depressions." Econometrica 1 (October): 337-57. 
Franken, H., G. Le Fort, and E. Parrado. 2005. "Business Cycle Dynamics and Shock Resilience in Chile." Working paper 331. Santiago: Central Bank of Chile.

Gallego, F. and N.V. Loayza. 2002. "The Golden Period for Growth in Chile: Explanations and Forecasts." Working paper 146. Santiago: Central Bank of Chile.

García, P. 2009. "Financial Turmoil, Illiquidity, and the Policy Response: The Case of Chile." Economic policy paper 29. Santiago: Central Bank of Chile.

Gupta, S. and J. Miniane. 2009. "Recessions and Recoveries in Asia: What Can the Past Teach Us about the Present Recession?" Asia Regional Economic Outlook (May): 29-41.

Hamilton, J. 2003. Comment on "A Comparison of Two Business Cycle Dating Methods." Journal of Economic Dynamics and Control 27(9): 1691-93.

Harding, D. and A. Pagan. 2002a. "A Comparison of Two Business Cycle Dating Methods." Journal of Economics Dynamics and Control 27(9): 1681-90.

_. 2002b. "Dissecting the Cycle: A Methodological Investigation." Journal of Monetary Economics 49(2): 365-81.

Hong, K., J.-W. Lee, and H.C. Tang. 2010. "Crises in Asia: Historical Perspectives and Implications." Journal of Asian Economics 21(3): 265-79.

IMF (International Monetary Fund). 1982. Article IV ConsultationStaff Report. Country report EBS.82/227. Washington: International Monetary Fund.

- 1983. Chile: Article IV Consultation-Staff Report. Country report EBS.84/50. Washington: International Monetary Fund.

- 2000. Chile: Article IV Consultation-Staff Report. IMF Country report SM 00/116. Washington: International Monetary Fund.

2008. Chile: Selected Issues, the Western Hemisphere Department. Country report 08/239. Washington: International Monetary Fund.

Jara, A., R. Moreno, and C.E. Tovar. 2009. "The Global Crisis and Latin America: Financial Impacts and Policy Responses." BIS Quarterly Review (June).

Kashyap, A.K. and J.C. Stein. 2000. "What Do a Million Observations on Banks Say about the Transmission of Monetary Policy?" American Economic Review 90(3): 407-28. 
Kose, M.A. 2002. "Explaining Business Cycles in Small Open Economies: How Much Do World Prices Matter?" Journal of International Economics 56(2): 299-327.

Kose, M.A., P. Loungani, and M.E. Terrones. 2009. "Out of the Ballpark." Finance and Development 46(2): 25-28.

Kose, M.A., E.S. Prasad, and M.E. Terrones. 2003. "How Does Globalization Affect the Synchronization of Business Cycles?" American Economic Review 93(2): 57-62.

. 2006. "How Do Trade and Financial Integration Affect the Relationship between Growth and Volatility?" Journal of International Economics 69(1): 176-202.

. 2009. "Does Financial Globalization Promote Risk Sharing?" Journal of Development Economics 89(2): 258-270.

Krugman, P. 1999. "Balance Sheets, the Transfer Problem, and Financial Crises." International Tax and Public Finance 6(4): 459-72.

Laeven, L. and F. Valencia. 2008. "Systemic Banking Crises: A New Database." Working paper 08/224. Washington: International Monetary Fund.

Larraín, M. 1989. "How the 1981-83 Chilean Banking Crisis Was Handled." Policy working paper 300. Washington: World Bank.

Medina, J.P. and C. Soto. 2007. "The Chilean Business Cycles through the Lens of a Stochastic General Equilibrium Model." Working paper 457. Santiago: Central Bank of Chile.

Mejía-Reyes, P. 1999. "Classical Business Cycles in Latin America: Turning Points, Asymmetries, and International Synchronization." Estudios Económicos 14: 265-97.

. 2004. "Classical Business Cycles in America: Are National Business Cycles Synchronised?" International Journal of Applied Econometrics and Quantitative Studies 1(3): 75-102.

Mendoza, E.G. 2010. "Sudden Stops, Financial Crises, and Leverage." American Economic Review 100(5): 1941-66.

Mendoza, E.G. and M.E. Terrones. 2008. "An Anatomy of Credit Booms: Evidence from Macro Aggregates and Micro Data." Working paper 14049. Cambridge, Mass.: National Bureau of Economic Research.

Neumeyer, P.A. and F. Perri. 2005. "Business Cycles in Emerging Economies: The Role of Interest Rates." Journal of Monetary Economics 52(2): 345-80.

Ocampo, J.A. 2009. "Latin America and the Global Financial Crisis." Cambridge Journal of Economics 33(4): 703-24. 
Reinhart, C. and K. Rogoff. 2009. "The Aftermath of Financial Crises." American Economic Review 99(2): 466-72.

Schneider, M. and A. Tornell. 2004. "Balance Sheet Effects, Bailout Guarantees, and Financial Crises." Review of Economic Studies 71(7): 883-913.

Simonovska, I. and L. Soderling. 2008. "Business Cycle Accounting for Chile." Working paper 08/61. Washington: International Monetary Fund.

Spilimbergo, A. 1999. "Copper and the Chilean Economy, 1960-98." Working paper 99/57. Washington: International Monetary Fund. 